\title{
Impact of Mining on Forests and Its Biological Diversity at Kirandul Iron Ore Mines, Dantewada, South Bastar, Chhattisgarh: A Case Study
}

\author{
Saroni Biswas ${ }^{1} \&$ Anirban Biswas ${ }^{2}$ \\ ${ }^{1}$ Development Research Communication and Services Centre, Bosepukur, Kasba, Kolkata, India \\ ${ }^{2}$ School of Environmental Studies, Jadavpur University, Kolkata, India \\ Correspondence: Anirban Biswas, School of Environmental Studies, Jadavpur University, Kolkata 700042, India. \\ Tel: 91-973-505-0085.
}

Received: June 21, 2018

Accepted: July 10, 2018

Online Published: July 17, 2018

doi:10.20849/jess.v1i1.420

URL: https://doi.org/10.20849/jess.v1i1.420

\begin{abstract}
Mining activities have several impacts on the environment. In our study, emphasis was given to assess biodiversity in one of the leading iron ore mining sites of Bailadila-Kirandul Iron Ore Mines (KIOM) of Dantewada District, South Bastar of Chhattisgarh. Habitat fragmentation, loss and deforestation are highly prevalent in the area. However, the study reveals high species richness of 110 and 253 plant species in core and buffer zone respectively. Canopy cover was found to be within 10 to $40 \%$ and in places in the buffer zone canopy cover with $>40 \%$ was recorded. Species diversity index indicates the instability of vegetation structure in the area with indices of 1.44 in core and 1.88 in buffer zone. Although species richness is high, about 10 floral species ( 7 herbs, 3 trees) are recorded under REET (Rare Endangered Extinct Threatened) species while locally endangered floral species are 6 and locally critically endangered are 4. Similarly, 208 faunal species belong to 10 faunal groups was recorded out of which 34 species are listed in different Schedules of Indian Wildlife (Protection) Act, 1972. Therefore, it is an urgent need for planning to undertake appropriate management strategies to conserve biodiversity in the area.
\end{abstract}

Keywords: biodiversity, species diversity, dominance, canopy statistics, life forms

\section{Introduction}

Significant and potential risks are found for tropical forests in the world due to mining processes. Globally, over the past 10 years, the mineral production have risen (Kooroshey et al., 2014). A study by Sonter et al., 2017 shows loss of Amazon forest of about $11,670 \mathrm{~km}^{2}$ area deforestation between the years 2005 to 2015 where $9 \%$ of the loss is contributed by mining leases. The area that includes extensive forest resources, in some of which mining - directly and/or indirectly — is thought to have contributed to significant deforestation (Swenson et al., 2011). Similarly, gold mining at Peruvian Amazon also resulted in deforestation (Asner et al., 2013). A sharp increase in mineral prices can result in a surge in mining activity, which contributes to deforestation in some locations. A study by the University of Puerto Rico found that tree cover loss in the Madre de Dios region of Peru has increased significantly since 2007 as a result of artisanal gold mining (Alvarez-Berríos \& Aide, 2015). Area of land involved in mining is small but it affects the surrounding area along with its species, and it is very intensive and very destructive (Mather, 1991; Sands, 2005). Mining is a lucrative activity promoting development booms which may attract population growth with consequent deforestation. The deforestation rate due to mining activities in Guyana from 2000 to 2008 increased 2.77 times according to an assessment by the World Wildlife Fund-Guianas (Staff, 2010). Similarly, in the Philippines, mining, along with logging, has been among the forces behind the country's loss of forest cover: from 17 million hectares in 1934 to just three million in 2003 or an 82 per cent decline (Docena, 2010). Nearly 2,000 hectares of tropical forest in the Municipality of Coahuayana in the State of Michoacán (south-western Mexico) will completely be destroyed by mining iron minerals planned by the Italo-Argentine mining company TERNIUM (Anonymous, 2008). Similarly, Nyamagari hills in Orissa India currently threatened by Vedanta Aluminum Corporation's plan to start bauxite mining will destroy 750 hectares of reserved forest (Griffiths \& Hirvela, 2008). Massive and unchecked mining of coal, iron ore and bauxite in Jharkhand, India has caused large scale deforestation and created a huge water scarcity (Anonymous, 2011). In return for US\$3.8 billion of investment, the agreements between the State government of Jharkhand, India and mining companies, there will be a massive land acquisition which will deforest no less than 57,000 hectares of forest and displace 9,615 families, many of them located in legally protected Scheduled Areas 
set aside for indigenous peoples in the State (Mullick \& Griffiths, 2007). Moreover, Roads constructed to support the mining operations will open up the area to shifting agriculturists, permanent farmers, ranchers, land speculators and infrastructure developers. For instance the core of Brazil's Amazon development strategy were infra-structure development projects such as roads providing access to frontier regions, mining area and large hydroelectric reservoirs (Mahar, 1988; Fearnside \& Barbosa, 1996; Carvalho et al., 2002, 2004).

Therefore, one of the key underlying assumptions about biodiversity management is that native species and ecological processes are most likely to be maintained. To maintain and strengthen the biodiversity management recommendations are primarily aimed at managed forests. The recommendations are designed to promote long term stand level maintenance and recruitment of important structural attributes such as: wildlife, diversity of species, special or unique habitats for floral and faunal wealth, riparian areas and wetlands, coarse woody debris, horizontal and vertical structural diversity.

National Mineral Development Corporation (NMDC) is India's single largest iron ore producer and exporter, presently producing about 30 million tons of iron ore from 3 fully mechanized mines viz., Bailadila Deposit-14/11C, Bailadila Deposit-5, 10/11A both within the state of Chhattisgarh and Kumaraswamy and Donimalai Iron Ore Mines (Karnataka State) which are awarded ISO 9001:2008, ISO 14001:2004 and OHSAS 18001:2007 certification. The iron Ores of Bailadila ranges being the purest in the world is valued highly in the international market. Bailadila range of hills has iron ore reserve of above 1500 million tons of high grade iron ore in 14 deposits.

Dantewada district has rich forest reserves with $64 \%$ of its land under forest cover and almost $79 \%$ tribal population. Although rich in natural wealth, the district has not seen much development, only $30 \%$ of the populations are literate and the district ranks seventh among the 150 backward districts of the country. Therefore the study area is selected to explore further for knowing the impacts of mining on forests. The main objective of the study is understanding various components of the ecosystems in the core as well as buffer zone and to study floral and faunal diversity in the proposed area of mines that aims to achieve the structural as well as functional aspects of it through proper management policies, and adopting scientific approach towards preparing biodiversity conservation and management plan to provide alternate habitat for existing flora and fauna in the ML as well as buffer zone.

\section{Method}

\subsection{Study Area}

Bailadila lies in the Survey of India topo-sheet no. $65 \mathrm{~F} / 2$ within latitude $18^{\circ} 32^{\prime} 32^{\prime \prime} \mathrm{N}$ and $19^{\circ} 36^{\prime} 5^{\prime \prime} \mathrm{N}$ and longitude $81^{\circ} 13^{\prime}$ and $81^{\circ} 14^{\prime} 30^{\prime \prime}$. The study area comes under Kirandul Iron Ore Mine (KIOM) (Figure 1). Total area within Kirandul Mining Project is 1364.115 ha under three deposits adjacent to reach other namely (i) Deposit-14 (322.368ha) ML area (ii) Deposit-14 NMZ (506.742ha) ML area and (iii) Deposit-11B (535.005 ha) ML area. The study covers $10 \mathrm{~km}$ radius around the core area.

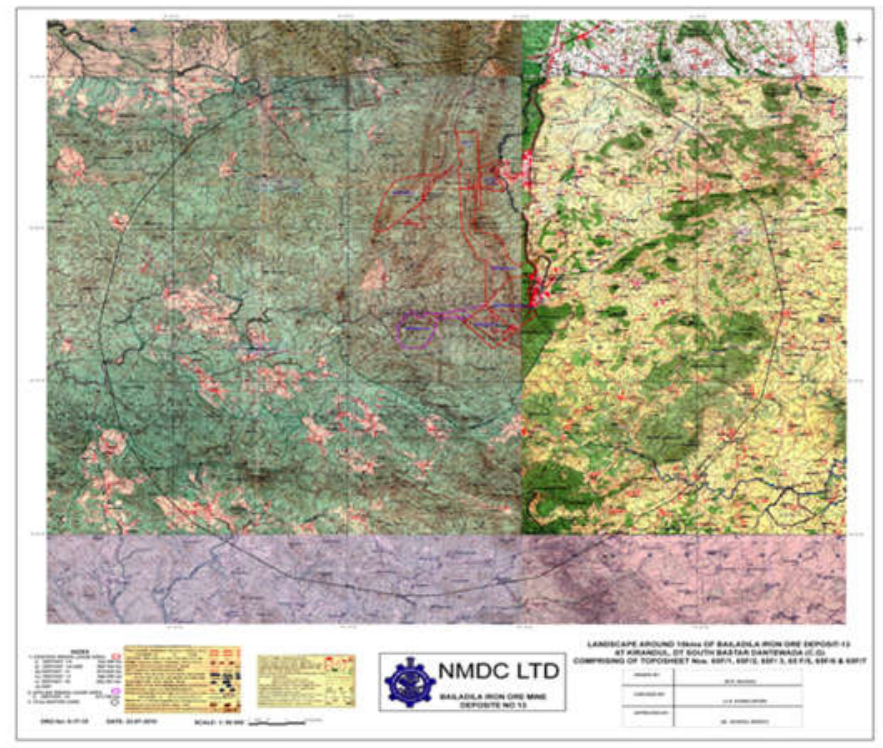

Figure 1. Location map of the iron ore deposits (Mining lease area) and buffer zone of 10km radius of study area 


\subsection{Drainage of Bailadila Range}

There are number of perennial streams flowing from the hills and the entire region is a part of Godavari basin. The eastern slopes drain through streams which flow towards northeast to Sankhini river. Drainage in between the eastern and western ridges is through two streams flowing in opposite direction, Galli nala towards south and Sankhini nala cuts across the eastern ridge near Jhirka village flows down east and north east and becomes the Sankini river. This joins with Dankini river near Dantewada and becomes Dantewada river, which ultimately flows through west and joins Indravati river. The western slopes drain through Mari nadi, Berudi nadi and other streams to river Indravti, which joins Godavari river near Bhopalpatnam in the downstream. Southern part of the complex drain through Malinger nadi joining Sabari rivedr and Galli nala joining Talperu river, all again flows to Godavari River.

\subsection{Geology}

The iron ores of Bailadila range belong to the Bailadila series which are associated with slightly metamorphosed iron-ore bearing sedimentary rocks of Pre-Cambrian age. Iron ore occurs as separate ore bodies on the crest of the two sub-parallel hills running north-south. These hill ranges comprises shales, banded hematite, quartzite and conglomerates containing pebbles of quartzite and shale.

\subsection{Sampling Technique}

Random samples were taken to assess the ecological structure of the study area and get some simple idea of the ecological functions. The study area is basically a hill running in East-West direction. The whole core area where mining activity is in progress is almost completely denuded and rarely has any species. In some places where species available was recorded as per the findings of transact walk. Random sampling was done with the help of Satellite Imagery and toposheet of the area. Samples were studied both within mining sites (ML area) and in the buffer area i.e., $10 \mathrm{~km}$ radius of the ML area of the three mines namely $14 \mathrm{ML}, 14 \mathrm{NMZ}$ and a part of $11 \mathrm{ML}$ i.e., 11B. Each site studied is marked with geographical coordinates recorded in GPS handset (GARMIN-12). Studies were done for understanding the phytosociology, inventorisation of faunal species as well as their habitat.

\subsection{Floral Study}

Quadrat sampling was done in the buffer zone only where there are both forest areas and non-forest areas. At the outset a species area curve was prepared in eastern side of the hill to find out the minimum size of the quadrat required for the study of three layers (considered as separate communities) such as tree, shrub and herb (Cain, 1938). It was inferred that for tree layer the minimum size of the quadrat required for study was $500 \mathrm{~m}^{2}(50 \mathrm{~m} X$ $10 \mathrm{~m})$ for trees, $(5 \mathrm{~m} \mathrm{X} 5 \mathrm{~m}) 25 \mathrm{~m}^{2}$ for shrubs and $(1 \mathrm{~m} \mathrm{X} 1 \mathrm{~m}) 1 \mathrm{~m}^{2}$ for herbs. In each of the sample sites a quadrat of $500 \mathrm{~m}^{2}$ was laid to study the tree community (Philip, 1959), Diversity Index, and Canopy Cover. In each of the tree quadrat four shrub quadrats were laid on alternate sides and similarly five herb quadrats were for study of herb layer. Each quadrat was given a code and marked by GPS reading. The sampling sites are as follows (Table 1).

Table 1. Location for vegetation enumeration in the study area

\begin{tabular}{|c|c|c|}
\hline \multicolumn{3}{|c|}{ Locations for vegetation study in Deposit-14 (Buffer Zone) } \\
\hline Sl. No. & Name of site & GPS bearing \\
\hline 1 & Kirandul station & $18^{\circ} 38^{\prime} 42.6^{\prime \prime} \mathrm{N} 81^{\circ} 16^{\prime} 0.7^{\prime \prime} \mathrm{E}$ Alt—625m \\
\hline 2 & Kadampal-Patelpara & $18^{\circ} 39^{\prime} 45.5^{\prime \prime} \mathrm{N} 81^{\circ} 18^{\prime} 7.1^{\prime \prime} \mathrm{E}$ Alt—575m \\
\hline 3 & Kadampal-Patelpara forest & $18^{\circ} 39^{\prime} 47^{\prime \prime} \mathrm{N} 81^{\circ} 17^{\prime} 47^{\prime \prime} \mathrm{E}$ Alt-575m \\
\hline 4 & Kadampal water body & $18^{\circ} 39^{\prime} 9.1^{\prime \prime} \mathrm{N} 81^{\circ} 17^{\prime} 41.8^{\prime \prime} \mathrm{E}$ Alt—583m \\
\hline 5 & Kirandul 4 no. area & $18^{\circ} 38^{\prime} 57.6^{\prime \prime} \mathrm{N} 81^{\circ} 16^{\prime} 3.7^{\prime \prime} \mathrm{E}$ Alt—618m \\
\hline 6 & Kirandul No.1 nala & $18^{\circ} 37^{\prime} 42.2^{\prime \prime} \mathrm{N} 8^{\circ} 15^{\prime} 51.7^{\prime \prime} \mathrm{E}$ Alt—638m \\
\hline 7 & Tailing Dam & $18^{\circ} 39^{\prime} 11.8^{\prime \prime} \mathrm{N} 81^{\circ} 17^{\prime} 6.2^{\prime \prime} \mathrm{E}$ Alt $-619 \mathrm{~m}$ \\
\hline 8 & Water body & $18^{\circ} 39^{\prime} 12.4^{\prime \prime} \mathrm{N} 81^{\circ} 17^{\prime} 0.3^{\prime \prime} \mathrm{E}$ Alt—595m \\
\hline 9 & Water body & $18^{\circ} 39^{\prime} 21.1^{\prime \prime} \mathrm{N} 81^{\circ} 17^{\prime} 16.1^{\prime \prime} \mathrm{E}$ Alt—581m \\
\hline 10 & Behind central workshop & $18^{\circ} 42^{\prime} 48.3^{\prime \prime} \mathrm{N} 81^{\circ} 15^{\prime} 56.8^{\prime \prime} \mathrm{E}$ Alt- $534 \mathrm{~m}$ \\
\hline 11 & Near Bacheli, a stream & $18^{\circ} 42^{\prime} 51^{\prime \prime N} 81^{\circ} 15^{\prime} 32.4^{\prime \prime} \mathrm{E}$ Alt-541m \\
\hline
\end{tabular}




\begin{tabular}{|c|c|c|}
\hline \multicolumn{3}{|c|}{ Locations for vegetation study in Deposit-14 (Buffer Zone) } \\
\hline Sl. No. & Name of site & GPS bearing \\
\hline 12 & Chalkipara & $18^{\circ} 41^{\prime} 37.7^{\prime \prime} \mathrm{N} 81^{\circ} 16^{\prime} 20.4^{\prime \prime} \mathrm{E}$ Alt-546m \\
\hline 13 & Foot hill near tailing pond & $18^{\circ} 40^{\prime} 32.4^{\prime \prime} \mathrm{N} 81^{\circ} 14^{\prime} 53.3^{\prime \prime} \mathrm{E}$ Alt-609m \\
\hline 14 & Middle of the hill & $18^{\circ} 40^{\prime} 29.8^{\prime \prime} \mathrm{N} 81^{\circ} 14^{\prime} 52.6^{\prime \prime} \mathrm{E}$ Alt-622m \\
\hline 15 & Top of the hill & $18^{\circ} 40^{\prime} 26.5^{\prime \prime} \mathrm{N} 81^{\circ} 14^{\prime} 50.5^{\prime \prime} \mathrm{E}$ Alt-642m \\
\hline 16 & Upper embankment of a pond & $18^{\circ} 40^{\prime} 33.9^{\prime \prime} \mathrm{N} 81^{\circ} 14^{\prime} 51.3^{\prime \prime} \mathrm{E}$ Alt-575m \\
\hline 17 & Middle embankment of a pond & $18^{\circ} 40^{\prime} 44.6^{\prime \prime} \mathrm{N} 81^{\circ} 14^{\prime} 55.2^{\prime \prime} \mathrm{E}$ Alt-599m \\
\hline 18 & Lower embankment of a pond & $18^{\circ} 40^{\prime} 36.9^{\prime \prime} \mathrm{N} 81^{\circ} 15^{\prime} 0.9^{\prime \prime} \mathrm{E}$ Alt—595m \\
\hline 19 & Malangir pump house & $18^{\circ} 35^{\prime} 30.8^{\prime \prime} \mathrm{N} 81^{\circ} 13^{\prime} 11.1^{\prime \prime} \mathrm{E}$ Alt-718m \\
\hline 20 & Malangir hill top & $18^{\circ} 35^{\prime} 27.8^{\prime \prime} \mathrm{N} 81^{\circ} 13^{\prime} 12.5^{\prime \prime} \mathrm{E}$ Alt-755m \\
\hline 21 & Malangir hill middle & $18^{\circ} 35^{\prime} 29.3^{\prime \prime} \mathrm{N} 81^{\circ} 13^{\prime} 12.7^{\prime \prime} \mathrm{E}$ Alt-744m \\
\hline 22 & Malangir foothill & $18^{\circ} 35^{\prime} 30.4^{\prime \prime} \mathrm{N} 81^{\circ} 13^{\prime} 11.2^{\prime \prime} \mathrm{E}$ Alt-733m \\
\hline 23 & $1 \mathrm{~km}$ advance to Malangir pump house & $18^{\circ} 35^{\prime} 40.5^{\prime \prime} \mathrm{N} 81^{\circ} 13^{\prime} 23.3^{\prime \prime} \mathrm{E}$ Alt-742m \\
\hline 24 & $2 \mathrm{~km}$ advance to Malangir pump house & $18^{\circ} 35^{\prime} 33.6^{\prime \prime} \mathrm{N} 81^{\circ} 13^{\prime} 41.7^{\prime \prime} \mathrm{E}$ Alt-742m \\
\hline 25 & $1.5 \mathrm{~km}$ advance to Malangir pump house & $18^{\circ} 35^{\prime} 27.6^{\prime \prime} \mathrm{N} 81^{\circ} 14^{\prime} 16.9^{\prime \prime} \mathrm{E}$ Alt-682m \\
\hline 26 & Hiroli Village — near agriculture land & $18^{\circ} 35^{\prime} 38.5^{\prime \prime} \mathrm{N} 81^{\circ} 15^{\prime} 23.5^{\prime \prime} \mathrm{E}$ Alt-682m \\
\hline 27 & Kirnar village & $18^{\circ} 36^{\prime} 26.5^{\prime \prime} \mathrm{N} 81^{\circ} 15^{\prime} 48.4^{\prime \prime} \mathrm{E}$ Alt-674m \\
\hline 28 & Near Ali Dongri & $18^{\circ} 37^{\prime} 36.9^{\prime \prime} \mathrm{N} 81^{\circ} 16^{\prime} 57.2^{\prime \prime} \mathrm{E}$ Alt—611 m \\
\hline 30 & Burdi Dongri & $18^{\circ} 37^{\prime} 40.9^{\prime \prime} \mathrm{N} 81^{\circ} 16^{\prime} 56.3^{\prime \prime} \mathrm{E}$ Alt—620 m \\
\hline 31 & Madari nala & $18^{\circ} 37^{\prime} 46^{\prime \prime} \mathrm{N} 81^{\circ} 17^{\prime} 5.3^{\prime \prime} \mathrm{E}$ Alt—614 m \\
\hline 32 & Patel para & $18^{\circ} 37^{\prime} 42.1^{\prime \prime} \mathrm{N} 81^{\circ} 17^{\prime} 39.8^{\prime \prime} \mathrm{E}$ Alt $-642 \mathrm{~m}$ \\
\hline 33 & Madadi village & $18^{\circ} 37^{\prime} 43.8^{\prime \prime} \mathrm{N} 81^{\circ} 17^{\prime} 58.9^{\prime \prime} \mathrm{E}$ Alt $-622 \mathrm{~m}$ \\
\hline 34 & Nayapara & $18^{\circ} 37^{\prime} 45.6^{\prime \prime} \mathrm{N} 81^{\circ} 18^{\prime} 01.5^{\prime \prime} \mathrm{E}$ Alt-623m \\
\hline 35 & Near Garma Dongri & $18^{\circ} 37^{\prime} 45.6^{\prime \prime} \mathrm{N} 81^{\circ} 18^{\prime} 01.5^{\prime \prime} \mathrm{E}$ Alt-623m \\
\hline 36 & Near Perpa Village & $18^{\circ} 37^{\prime} 23^{\prime \prime} \mathrm{N} 81^{\circ} 16^{\prime} 45.5^{\prime \prime} \mathrm{E}$ Alt—623m \\
\hline 37 & Near ESSAR plant & $18^{\circ} 37^{\prime} 29.1^{\prime \prime} \mathrm{N} 81^{\circ} 15^{\prime} 51.5^{\prime \prime} \mathrm{E}$ Alt-619m \\
\hline \multicolumn{3}{|c|}{ Locations for vegetation study in Deposit—14NMZ (Buffer Zone) } \\
\hline 1 & Near Bhannara hill & $18^{\circ} 44^{\prime} 9.1^{\prime \prime} \mathrm{N} 81^{\circ} 16^{\prime} 20.8^{\prime \prime} \mathrm{E}$ Alt—488m \\
\hline 2 & Behind central workshop & $18^{\circ} 42^{\prime} 48.3^{\prime \prime} \mathrm{N} 81^{\circ} 15^{\prime} 56.8^{\prime \prime} \mathrm{E}$ Alt-534m \\
\hline 3 & Near Bacheli, a stream & $18^{\circ} 42^{\prime} 51^{\prime \prime} \mathrm{N} 81^{\circ} 15^{\prime} 32.4^{\prime \prime} \mathrm{E}$ Alt—541m \\
\hline 4 & Chalkipara & $18^{\circ} 41^{\prime} 37.7^{\prime \prime} \mathrm{N} 81^{\circ} 16^{\prime} 20.4^{\prime \prime} \mathrm{E}$ Alt-546m \\
\hline 5 & Pina bacheli & $18^{\circ} 41^{\prime} 44.3^{\prime \prime} \mathrm{N} 81^{\circ} 17^{\prime} 54.3^{\prime \prime} \mathrm{E}$ Alt-532m \\
\hline 6 & Dugeli & $18^{\circ} 41^{\prime} 36^{\prime \prime} \mathrm{N} 81^{\circ} 18^{\prime} 41^{\prime \prime} \mathrm{E}$ Alt—546m \\
\hline 7 & Kirandul No.1 nala & $18^{\circ} 37^{\prime} 42.2^{\prime \prime} \mathrm{N} 81^{\circ} 15^{\prime} 51.7^{\prime \prime} \mathrm{E}$ Alt-638m \\
\hline 8 & Tailing Dam & $18^{\circ} 39^{\prime} 11.8^{\prime \prime} \mathrm{N} 81^{\circ} 17^{\prime} 6.2^{\prime \prime} \mathrm{E}$ Alt—619m \\
\hline 9 & Water body & $18^{\circ} 39^{\prime} 12.4^{\prime \prime} \mathrm{N} 81^{\circ} 17^{\prime} 0.3^{\prime \prime} \mathrm{E}$ Alt—595m \\
\hline 10 & Water body & $18^{\circ} 39^{\prime} 21.1^{\prime \prime} \mathrm{N} 81^{\circ} 17^{\prime} 16.1^{\prime \prime} \mathrm{E}$ Alt-581m \\
\hline 11 & Near Ali Dongri & $18^{\circ} 37^{\prime} 36.9^{\prime \prime} \mathrm{N} 81^{\circ} 16^{\prime} 57.2^{\prime \prime} \mathrm{E}$ Alt-611 m \\
\hline 12 & Burdi Dongri & $18^{\circ} 37^{\prime} 40.9^{\prime \prime} \mathrm{N} 81^{\circ} 16^{\prime} 56.3^{\prime \prime} \mathrm{E}$ Alt—620 m \\
\hline 13 & Madari nala & $18^{\circ} 37^{\prime} 46^{\prime \prime} \mathrm{N} 81^{\circ} 17^{\prime} 5.3^{\prime \prime} \mathrm{E}$ Alt $-614 \mathrm{~m}$ \\
\hline 14 & Patel para & $18^{\circ} 37^{\prime} 42.1^{\prime \prime} \mathrm{N} 81^{\circ} 17^{\prime} 39.8^{\prime \prime} \mathrm{E}$ Alt—642 m \\
\hline
\end{tabular}




\begin{tabular}{|c|c|c|}
\hline \multicolumn{3}{|c|}{ Locations for vegetation study in Deposit-14 (Buffer Zone) } \\
\hline Sl. No. & Name of site & GPS bearing \\
\hline 15 & Madadi village & $18^{\circ} 37^{\prime} 43.8^{\prime \prime} \mathrm{N} 81^{\circ} 17^{\prime} 58.9^{\prime \prime} \mathrm{E}$ Alt—622 m \\
\hline 16 & Nayapara & $18^{\circ} 37^{\prime} 45.6^{\prime \prime} \mathrm{N} 81^{\circ} 18^{\prime} 01.5^{\prime \prime} \mathrm{E}$ Alt-623m \\
\hline 17 & Near Garma Dongri & $18^{\circ} 37^{\prime} 45.6^{\prime \prime} \mathrm{N} 81^{\circ} 18^{\prime} 01.5^{\prime \prime} \mathrm{E}$ Alt-623m \\
\hline 18 & Near Perpa Village & $18^{\circ} 37^{\prime} 23^{\prime \prime} \mathrm{N} 81^{\circ} 16^{\prime} 45.5^{\prime \prime} \mathrm{E}$ Alt-623m \\
\hline 19 & Near ESSAR plant & $18^{\circ} 37^{\prime} 29.1^{\prime \prime} \mathrm{N} 81^{\circ} 15^{\prime} 51.5^{\prime \prime} \mathrm{E}$ Alt- $619 \mathrm{~m}$ \\
\hline 20 & Malenger pump house & $18^{\circ} 35^{\prime} 30.8^{\prime \prime} \mathrm{N} 81^{\circ} 13^{\prime} 11.1^{\prime \prime} \mathrm{E}$ Alt-718m \\
\hline 21 & Malenger hill top & $18^{\circ} 35^{\prime} 27.8^{\prime \prime} \mathrm{N} 81^{\circ} 13^{\prime} 12.5^{\prime \prime} \mathrm{E}$ Alt-755m \\
\hline 22 & Malenger hill middle & $18^{\circ} 35^{\prime} 29.3^{\prime \prime} \mathrm{N} 81^{\circ} 13^{\prime} 12.7^{\prime \prime} \mathrm{E}$ Alt-744m \\
\hline 23 & Malenger foothill & $18^{\circ} 35^{\prime} 30.4^{\prime \prime} \mathrm{N} 81^{\circ} 13^{\prime} 11.2^{\prime \prime} \mathrm{E}$ Alt-733m \\
\hline 24 & $1 \mathrm{~km}$ advance to Malenger pump house & $18^{\circ} 35^{\prime} 40.5^{\prime \prime} \mathrm{N} 81^{\circ} 13^{\prime} 23.3^{\prime \prime} \mathrm{E}$ Alt-742m \\
\hline 25 & $2 \mathrm{~km}$ advance to Malenger pump house & $18^{\circ} 35^{\prime} 33.6^{\prime \prime} \mathrm{N} 81^{\circ} 13^{\prime} 41.7^{\prime \prime} \mathrm{E}$ Alt-742m \\
\hline 26 & $1.5 \mathrm{~km}$ advance to Malenger pump house & $18^{\circ} 35^{\prime} 27.6^{\prime \prime} \mathrm{N} 81^{\circ} 14^{\prime} 16.9^{\prime \prime}$ E Alt-682m \\
\hline 27 & Hiroli Village—near agriculture land & $18^{\circ} 35^{\prime} 38.5^{\prime \prime} \mathrm{N} 81^{\circ} 15^{\prime} 23.5^{\prime \prime} \mathrm{E}$ Alt-682m \\
\hline 28 & Kirnar village & $18^{\circ} 36^{\prime} 26.5^{\prime \prime} \mathrm{N} 81^{\circ} 15^{\prime} 48.4^{\prime \prime} \mathrm{E}$ Alt-674m \\
\hline 29 & Between Bennar hill and Bennar village & $18^{\circ} 43^{\prime} 3.7^{\prime \prime} \mathrm{N} 81^{\circ} 17^{\prime} 42.5^{\prime \prime} \mathrm{E}$ Alt—502m \\
\hline 30 & Bennar village & $18^{\circ} 43^{\prime} 2.5^{\prime \prime} \mathrm{N} 81^{\circ} 17^{\prime} 19.1^{\prime \prime} \mathrm{E}$ Alt— $498 \mathrm{~m}$ \\
\hline 31 & Bennar nala & $18^{\circ} 43^{\prime} 8.8^{\prime \prime} \mathrm{N} 81^{\circ} 17^{\prime} 7.1^{\prime \prime} \mathrm{E}$ Alt—487m \\
\hline 32 & Kirandul 4 no. area & $18^{\circ} 38^{\prime} 57.6^{\prime \prime} \mathrm{N} 81^{\circ} 16^{\prime} 3.7^{\prime \prime} \mathrm{E}$ Alt—618m \\
\hline \multicolumn{3}{|c|}{ Locations for vegetation study in Deposit-11B (Buffer Zone) } \\
\hline 1 & Kirandul station & $18^{\circ} 38^{\prime} 42.6^{\prime \prime} \mathrm{N} 81^{\circ} 16^{\prime} 0.7^{\prime \prime} \mathrm{E}$ Alt—625m \\
\hline 2 & Kadampal_Patelpara & $18^{\circ} 39^{\prime} 45.5^{\prime \prime} \mathrm{N} 81^{\circ} 18^{\prime} 7.1^{\prime \prime} \mathrm{E}$ Alt—575m \\
\hline 3 & Kadampal—Patelpara forest & $18^{\circ} 39^{\prime} 47^{\prime \prime} \mathrm{N} 81^{\circ} 17^{\prime} 47^{\prime \prime} \mathrm{E}$ Alt-575m \\
\hline 4 & Kadampal water body & $18^{\circ} 39^{\prime} 9.1^{\prime \prime} \mathrm{N} 81^{\circ} 17^{\prime} 41.8^{\prime \prime} \mathrm{E}$ Alt-583m \\
\hline 5 & Hiroli Village — near agriculture land & $18^{\circ} 35^{\prime} 38.5^{\prime \prime} \mathrm{N} 81^{\circ} 15^{\prime} 23.5^{\prime \prime} \mathrm{E}$ Alt-682m \\
\hline 6 & Near Ali Dongri & $18^{\circ} 37^{\prime} 36.9^{\prime \prime} \mathrm{N} 81^{\circ} 16^{\prime} 57.2^{\prime \prime} \mathrm{E}$ Alt $-611 \mathrm{~m}$ \\
\hline 7 & Burdi Dongri & $18^{\circ} 37^{\prime} 40.9^{\prime \prime} \mathrm{N} 81^{\circ} 16^{\prime} 56.3^{\prime \prime} \mathrm{E}$ Alt $-620 \mathrm{~m}$ \\
\hline 8 & Madari nala & $18^{\circ} 37^{\prime} 46^{\prime \prime} \mathrm{N} 81^{\circ} 17^{\prime} 5.3^{\prime \prime} \mathrm{E}$ Alt—614 m \\
\hline 9 & Patel para & $18^{\circ} 37^{\prime} 42.1^{\prime \prime} \mathrm{N} 81^{\circ} 17^{\prime} 39.8^{\prime \prime} \mathrm{E}$ Alt-642 m \\
\hline 10 & Madadi village & $18^{\circ} 37^{\prime} 43.8^{\prime \prime} \mathrm{N} 81^{\circ} 17^{\prime} 58.9^{\prime \prime} \mathrm{E}$ Alt—622 m \\
\hline 11 & Nayapara & $18^{\circ} 37^{\prime} 45.6^{\prime \prime} \mathrm{N} 81^{\circ} 18^{\prime} 01.5^{\prime \prime} \mathrm{E}$ Alt-623m \\
\hline 12 & Near Garma Dongri & $18^{\circ} 37^{\prime} 45.6^{\prime \prime} \mathrm{N} 81^{\circ} 18^{\prime} 01.5^{\prime \prime} \mathrm{E}$ Alt-623m \\
\hline 13 & Near Perpa Village & $18^{\circ} 37^{\prime} 23^{\prime \prime} \mathrm{N} 81^{\circ} 16^{\prime} 45.5^{\prime \prime} \mathrm{E}$ Alt—623m \\
\hline 14 & Near ESSAR plant & $18^{\circ} 37^{\prime} 29.1^{\prime \prime} \mathrm{N} 81^{\circ} 15^{\prime} 51.5^{\prime \prime} \mathrm{E}$ Alt-619m \\
\hline 15 & Kirandul 4 no. Area & $18^{\circ} 38^{\prime} 57.6^{\prime \prime} \mathrm{N} 81^{\circ} 16^{\prime} 3.7^{\prime \prime} \mathrm{E}$ Alt—618m \\
\hline 16 & Kirandul No.1 nala & $18^{\circ} 37^{\prime} 42.2^{\prime \prime} \mathrm{N} 81^{\circ} 15^{\prime} 51.7^{\prime \prime} \mathrm{E}$ Alt-638m \\
\hline 17 & Tailing Dam & $18^{\circ} 39^{\prime} 11.8^{\prime \prime} \mathrm{N} 81^{\circ} 17^{\prime} 6.2^{\prime \prime} \mathrm{E}$ Alt—619m \\
\hline 18 & Water body & $18^{\circ} 39^{\prime} 12.4^{\prime \prime} \mathrm{N} 81^{\circ} 17^{\prime} 0.3^{\prime \prime} \mathrm{E}$ Alt—595m \\
\hline 19 & Water body & $18^{\circ} 39^{\prime} 21.1^{\prime \prime} \mathrm{N} 81^{\circ} 17^{\prime} 16.1^{\prime \prime} \mathrm{E}$ Alt-581m \\
\hline 20 & Malenger pump house & $18^{\circ} 35^{\prime} 30.8^{\prime \prime} \mathrm{N} 81^{\circ} 13^{\prime} 11.1^{\prime \prime} \mathrm{E}$ Alt-718m \\
\hline 21 & Malenger hill top & $18^{\circ} 35^{\prime} 27.8^{\prime \prime} \mathrm{N} 81^{\circ} 13^{\prime} 12.5^{\prime \prime} \mathrm{E}$ Alt-755m \\
\hline
\end{tabular}




\begin{tabular}{|c|c|c|}
\hline \multicolumn{3}{|c|}{ Locations for vegetation study in Deposit-14 (Buffer Zone) } \\
\hline Sl. No. & Name of site & GPS bearing \\
\hline 22 & Malenger hill middle & $18^{\circ} 35^{\prime} 29.3^{\prime \prime} \mathrm{N} 81^{\circ} 13^{\prime} 12.7^{\prime \prime} \mathrm{E}$ Alt—744m \\
\hline 23 & Malenger foothill & $18^{\circ} 35^{\prime} 30.4^{\prime \prime} \mathrm{N} 81^{\circ} 13^{\prime} 11.2^{\prime \prime} \mathrm{E}$ Alt-733m \\
\hline 24 & $1 \mathrm{~km}$ advance to Malenger pump house & $18^{\circ} 35^{\prime} 40.5^{\prime \prime} \mathrm{N} 81^{\circ} 13^{\prime} 23.3^{\prime \prime} \mathrm{E}$ Alt-742m \\
\hline 25 & $2 \mathrm{~km}$ advance to Malenger pump house & $18^{\circ} 35^{\prime} 33.6^{\prime \prime} \mathrm{N} 81^{\circ} 13^{\prime} 41.7^{\prime \prime} \mathrm{E}$ Alt-742m \\
\hline 26 & $1.5 \mathrm{~km}$ advance to Malenger pump house & $18^{\circ} 35^{\prime} 27.6^{\prime \prime} \mathrm{N} 81^{\circ} 14^{\prime} 16.9^{\prime \prime} \mathrm{E}$ Alt-682m \\
\hline 27 & Hiroli Village - near agriculture land & $18^{\circ} 35^{\prime} 38.5^{\prime \prime} \mathrm{N} 81^{\circ} 15^{\prime} 23.5^{\prime \prime} \mathrm{E}$ Alt-682m \\
\hline 28 & Kirnar village & $18^{\circ} 36^{\prime} 26.5^{\prime \prime} \mathrm{N} 81^{\circ} 15^{\prime} 48.4^{\prime \prime} \mathrm{E}$ Alt-674m \\
\hline 29 & Behind central workshop & $18^{\circ} 42^{\prime} 48.3^{\prime \prime} \mathrm{N} 81^{\circ} 15^{\prime} 56.8^{\prime \prime} \mathrm{E}$ Alt-534m \\
\hline 30 & Near Bacheli, a stream & $18^{\circ} 42^{\prime} 51^{\prime \prime} \mathrm{N} 81^{\circ} 15^{\prime} 32.4^{\prime \prime} \mathrm{E}$ Alt-541m \\
\hline 31 & Chalkipara & $18^{\circ} 41^{\prime} 37.7^{\prime \prime} \mathrm{N} 81^{\circ} 16^{\prime} 20.4^{\prime \prime} \mathrm{E}$ Alt-546m \\
\hline
\end{tabular}

\subsection{Canopy Statistics}

A geometric measurement was adopted to estimate Canopy Cover, by directly measuring the crown diameters at right angles, in a specified quadrat. The total canopy cover area (C) in a sample quadrat equals the sum total of the canopy areas of all trees within the quadrat, $\Sigma \pi r_{\mathrm{i}}^{2}$. Thus, the Canopy Cover Index (CC) is the ratio of $\mathrm{C}$ to $A$, where $A=\mathrm{XY}$ (X and Y denoting axes of the quadrat being measured). Open canopy is inferred when $\mathrm{CC}<0.4$.

\subsection{Species Diversity (Alpha Diversity)}

Since Shannon and Wiener's $H^{\prime}$ is an index of information, it was employed to measure diversity of any assemblage (Shannon \& Wiener, 1963). The Simpson's Dominance Index (D) was also calculated (Simpson, 1949).

\subsection{Life Form Study}

The life form composition of the community is the manifestation of the adaptations of its component species to the climatic condition, and contributes to community architecture (Jamir et al., 2006). Life form spectrum is the sum of adaptations of plants to the climate. Following the system of Braun-Blanquet's (1951) system the area possesses five major classes like Phanerophytes, Therophytes, Hydrophytes, Hemicryptophytes and Geophytes.

\subsection{Taxonomic Identification of Plant Species}

Plant species were identified following standard flora by Hooker (1872-1897), Verma et al. (1985) and Kumar et al., (2005). Names of the plant species were verified using Bennet (1987). The help of scientists of Botanical survey of India (BSI), Kolkata was taken.

\subsection{Faunal Study}

An ecological survey of the study area for understanding the fauna of the study area was conducted, particularly with reference to listing of species and assessment of the existing baseline ecological conditions in the study area through Direct Count Method; Transect Method; Photographic-survey Based; Dropping/scat; Collection of dissociable body parts and Interviewing Local Villagers.

The study was conducted during post monsoon season in the year 2015-16. The study for fauna was conducted before sunrise to late night (5:30AM to 11:30PM). The adults of Odonata, Lepidoptera and Hymenoptera were collected in the field with aspirator, manually and aerial sweeping nets. The collected insects were preserved by using benzene and kept in insect collection boxes for further examination in the laboratory. Mollusca, Amphibians and Reptiles were collected with the help of forceps manually and Fishes with the help of Aquatic net and all the materials preserved in $70 \%$ Alcohol. The random collection and field observation were also made on different groups of the fauna of the study area. The Reptiles, Aves and Mammals were identified by using Binocular $(10 \mathrm{~mm}$ X $25 \mathrm{~mm})$ and their presence was recorded by taking photographs. The presence of some Mammals species is also ascertained on the basis of pugmarks, interview with wildlife and forest officials, NMDC staff and villagers residing in study area (Sunquist, 1981; Tamang, 1982; McDougal, 1997; Srestha \& Basnet, 2005). 


\section{Result and Discussion}

\subsection{Status of Phytodiversity}

Bailadila Reserve Forest can prove to be a paradise for both plant and wildlife diversity. The Dantewada district of Chhattisgarh lies on the Gondwana Biodiversity Zone, which mostly comprises of the Tropical Forests. As this area is full of terrains, much of the forest remains unexplored and it is highly probable that this area contains some of the undocumented species. The forest area in the buffer zone comes under Reserve Forest and has following classes as per classification of Forest Survey of India.

(i) Closed Forest/Very Dense Forest—Where canopy cover is above $70 \%$

(ii) Dense Forest-Where canopy cover is between $40 \%-70 \%$

(iii) Open Forest-Where canopy cover is between 10\%-40\%

(iv) Degraded Forest-Where canopy cover is below $10 \%$

The vegetation occurring in the area belongs to Southern tropical dry deciduous forests (Class-5A) which intermingles with Class-5B (Northern tropical dry deciduous type) according to Champion and Seth Classification of forest types of India 1968. According to the classification of Legris and Pascal (1982) the area falls under Deciduous climax forests and this type of forests does not have the potentiality of secondary moist deciduous forests. The most characteristic tree of this type is Anogeissus latifolia while Terminalia tomentosa is a very typical associate. Diospyros melanoxylon is also common. Boswellia serrata and Lagersatroemia parviflora are very wide spread and conspicuous in this category of forests. Bamboo is generally of poor quality. Grass is conspicuous till it is grazed or burnt in forest fire. Woody climbers are few like Bauhinia vahlii. This type of forest, being especially prevalent in the drier localities occurs throughout the study area. But the rain fall being around $3000 \mathrm{~mm}$ annually it can hardly be classified under dry forest type. Therefore some patches can be classified under Tropical Moist Deciduous Forest with types as $3 \mathrm{~B} / \mathrm{C}_{1}$ and $3 \mathrm{~B} / \mathrm{C}_{2}$. In this type of forests, trees are comparatively tall. It has a leafless period during dry season which may or may not begin with the cold weather.

The boundaries of biogeographic provinces i.e., Eastern Plateau (6B2) and Eastern Highlands (6C2) are not very sharp and they inter-grade into each other. Interestingly the recent physiographic map adopted by the Forest Survey of India also classifies this region into three zones viz., North Deccan, East Deccan and South Deccan by apparently giving more weightage to the political boundary between Maharashtra and Chhattisgarh. The entire area forms the South-Western and Westernmost part of historical Dandakaranya region. This region extends up to North-Eastern Ghats.

The top canopy remains leafless between February-May. The under storey is well defined and the forest floor is full of vegetal growth. Portions of moist deciduous forests were clear felled and converted into plantations of different species such as Teak (Tectona grandis), Eucalyptus sps, etc. But none of these species being indigenous to this region and planted without any ecological impact study could not successfully establish themselves. In some of the plantation area invasive species like Lanatana camara and/or Eupatorium odoratum has invaded. The adjacent areas to drainage nallas show rich vegetation whereas the hill top shows barren condition with clear signs of laterization. In the hill top soil formation process is poor and simultaneously there is rapid washing out of top soil.

In the hilly areas of Bailadila, availability of iron ore and vegetation change with altitude. According to Mooney (1942a), vegetation at the study area is divided into three zones and has been sub-divided to different associations depending upon various sites in the hill range as,

i. The outer slope of the Hill Range up to an altitude above $914 \mathrm{~m}$ above sea level-Northern portion of the hill "vegetation is of Hill type with dense bamboo" with evergreen species like Sataparni (Alstonia scholaris), Garari (Cleistanthus collinus), and Bauhinia vahlli. In the southern half of the hill species like Haldu (Adina cordifolia), and Mahua (Madhuca indica) are available in low quantity. Bijasal (Pterocarpus marsupium) with good girth size is found in this side.

ii. The crest of the Hill Range and the adjoining slope - this comes within $914 \mathrm{~m}$ to $1224 \mathrm{~m}$ above MSL. This region has high rock content and laterite with low soil content. Trees are stunted, sparse and dense grass (Physalanona $s p$ ) noticed. Tree species are Saja (Terminalia alata), Tendu (Diospyros melanoxylon), Awnla (Emblica officinalis), Achar (Buchanania latifolia), Harra (Terminalia chebula), and Sal (Shorea robusta), etc. Mooney (1942b) has described this grass dominated region as sub-climax or pro-climax type as a result of shifting cultivation that was in practice even few years back. 
iii. The Central valley - the central valley do not come under the study site but is in the buffer area - has species like Saja (Terminalia alata), Bijasal (Pterocarpus marsupium), Kusum (Schleichera oleosa), Semal (Bombax ceiba), Kala-Siris (Albizzia lebbbek), and Kadamba (Anthocephalus cadamba), etc. Bamboo is conspicuously low in this region. Here are few types of forests dominated by species as stated below provided undisturbed: Saja forest, Dhaora (Anogeisus latifolia) forest, Garari (Cleistanthus collinus) forest, Bhirra (Chloroxylon swietenia) forest, Khair (Acacia catechu) forest, Jamun (Syzygium cumini) forest, Anjan (Hardwickia binata) forest, and Mixed Forest with miscellaneous species.

The major floral associations of the forest area of Bailadila are grouped under the following six categories basing on the description of earlier authors and present study of IVI (Table 2).

Table 2. Floral association of the study area

\begin{tabular}{ll}
\hline $\begin{array}{l}\text { Acacia catechu } \\
\text { (Khair) }\end{array}$ & $\begin{array}{l}\text { The coarse gravelly soil supports the xerophytic growth of Khair. The forests are } \\
\text { generally open. Quality of the crop and natural reproduction is generally poor. }\end{array}$ \\
\hline $\begin{array}{l}\text { Anogeissus latifolia } \\
\text { (Dhaora) }\end{array}$ & $\begin{array}{l}\text { The most common constituent of the mixed deciduous forests, often growing more or } \\
\text { less gregariously. Avoids swampy and badly drained grounds and requires good } \\
\text { drainage. It produces abundant natural regeneration but most of it gets severely } \\
\text { damaged and killed in areas with low density due to severe annual forest fires. }\end{array}$ \\
$\begin{array}{l}\text { Chloroxylon } \\
\text { Swietenia (Bhirra) }\end{array}$ & $\begin{array}{l}\text { Patches of practically pure Garai forest are sometimes seen in the mixed forests in } \\
\text { (Ghich there are very few associates in the overwood. The reasons for its occurrence in }\end{array}$ \\
(Garai) & $\begin{array}{l}\text { a gregarious form are not quite understood. This sub-type forms an important future } \\
\text { reserve for poles and fuel. Density is generally full. }\end{array}$ \\
$\begin{array}{l}\text { Syzygium cumini } \\
\text { (Jumun) }\end{array}$ & $\begin{array}{l}\text { Commonly found in the open forests of Gollapalli, Nilamadugu and Kollaiguda } \\
\text { reserves and some of the reserves of Sukma range. It exhibits xerophytic characters and } \\
\text { is narrow leaved. Its seedlings die back annually for some years in their early stages. }\end{array}$ \\
$\begin{array}{l}\text { Terminalia alata } \\
\text { (Saja) }\end{array}$ & $\begin{array}{l}\text { It alone thrives in such places where the soil is moist but somewhat heavy owing to the } \\
\text { presence of fine clay, where the drainage is hampered and the species are that are } \\
\text { susceptible to bad soil aeration disappear. }\end{array}$ \\
$\begin{array}{l}\text { Hardwickia binata } \\
\text { (Anjan) }\end{array}$ & $\begin{array}{l}\text { It is scattered in the southern portion of Gollapalli reserve. This has probably spread } \\
\text { from the adjoining area of Andhra Pradesh where it is commonly seen. The areas under } \\
\text { this sub-type are not much of any economic importance. }\end{array}$ \\
\hline
\end{tabular}

\subsection{Life Form Status}

Life-form refers rather to the vegetative form of the plant body which is assumed by many ecologists to be a result of morphological adjustments to the environment. Those organisms which show the same general morphological features (woody lianas, stem succulents, annuals, tap-rooted perennials with a basal rosette of leaves and the renewal bud at the soil surface, tall broad-leaf deciduous trees, etc.) belong to the same life-form whatever their systematic position in the plant families. It is inherent in the so-called "biological" concept of life-form that there is a fundamental harmony or analogy between the members of such structural groups and the environment in which they prevail. Presence of large percentage of phanerophytes (trees and shrubs) and therophytes (annuals and herbaceous vegetation) indicates semiarid to tropical vegetation structure. The life form status of the study area is given in Figure 2. 


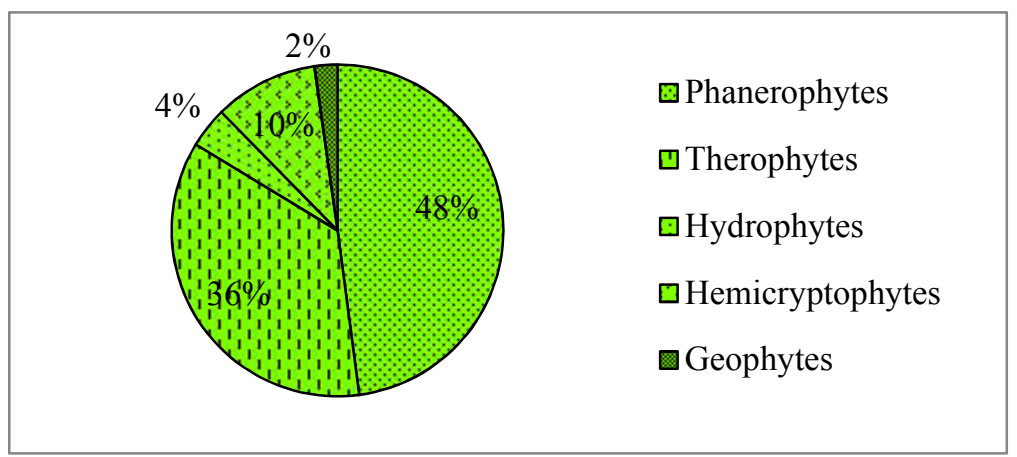

Figure 2. Life form in core and buffer zone

\subsection{Vegetation within ML Area}

The three mines within Kirandul Complex namely Deposit-14, 14 NMZ and a part of 11 (11B) have a very large area given to NMDC for mining as mined lease area and is almost broken. In spite of all out mining activities in all the mining leases as stated above Deposit-14 has 101 floral species within it. This includes 18 tree species, 26 species of shrubs and 57 species of herbs. Mining lease 14 NMZ has 80 floral species within it. This includes 17 tree species, 18 species of shrubs and 44 species of herbs. A part of mining lease 11 (11B) has 93 floral species within it. This includes 21 tree species, 24 species of shrubs and 48 species of herbs. Trees from Fabaceae family include species like Butea monosperma and Cassia fistula. Within the members of Poaceae Thysanolaena maxima is seen very frequently around comparatively stable broken area. There are species like Parthenium hysterophorus which are alien and also invasive in nature.

The three core zones in total have 110 species and maximum number of species is observed in ML-14 (Table 3). This is due to the fact that there is a good patch of vegetation within the ML area of Deposit-14 on both sides of Dhobinala. This is a perennial stream and it originates just below the waste dump of the deposit. The other two deposits have less number of species due to lack of any forest patch. The species that are available are mostly in the road sides and slopes where anthropogenic interventions are least.

Table 3. List of plant species at core area of Kirandul Iron Ore Mine

\begin{tabular}{ccc}
\hline Sl. No. & Scientific name of the species & Family \\
\hline Tree & & \\
\hline 1 & Acacia auriculiformis & Fabaceae \\
2 & Adina cordifolia & Rubiaceae \\
3 & Aegle mermelos & Rutaceae \\
4 & Albizzia procera & Fabaceae \\
5 & Bauhinia acuminate & Fabaceae \\
6 & Boswellia serreta & Burseraceae \\
7 & Buchanania lanzen & Anacardiaceae \\
8 & Butea monosperma & Fabaceae \\
9 & Cassia fistula & Fabaceae \\
10 & Cedrela tonna & Meliaceae \\
11 & Cliestanthus collinus & Euphorbiaceae \\
12 & Dillenia pentagyna & Dilleniaceae \\
13 & Diospyros melanoxylon & Ebnaceae \\
14 & Emblica officinales & Euphorbiaceae \\
15 & Ixora arborea & Rubiaceae \\
16 & Kydia sp. & Malvaceae \\
\hline
\end{tabular}




\begin{tabular}{|c|c|c|}
\hline Sl. No. & Scientific name of the species & Family \\
\hline \multicolumn{3}{|l|}{ Tree } \\
\hline 17 & Lagerstromea perviflora & Lythraceae \\
\hline 18 & Lannea coromandelica & Anacardiaceae \\
\hline 19 & Phoenix sylvestris & Arecaceae \\
\hline 20 & Sleichera oliosa & Sapindaceae \\
\hline 21 & Soymida febrifuga & Meliaceae \\
\hline 22 & Syzizium cumini & Myrtaceae \\
\hline 23 & Terminalia belerica & Combretaceae \\
\hline 24 & Terminalia tomentosa & Combretaceae \\
\hline 25 & Trema orientalis & Urticaceae \\
\hline \multicolumn{3}{|l|}{ Shrub } \\
\hline 1 & Asparagus racemosus & Liliaceae \\
\hline 2 & Bauhinia vahlii & Fabaceae \\
\hline 3 & Caesalpinia bonducella & Caesalpiniaceae \\
\hline 4 & Calotropis procera & Asclepiadaceae \\
\hline 5 & Capparis spinosa & Capparidaceae \\
\hline 6 & Casiarea varacca & Samydaceae \\
\hline 7 & Coccinia grandis (= Cephalandra indica) & Cucurbitaceae \\
\hline 8 & Cryptolepis buchanani & Apocynaceae \\
\hline 9 & Dioscorea bulbifera & Dioscoreaceae \\
\hline 10 & Flacourtia ramontchi & Flacourtiaceae \\
\hline 11 & Gardenia gummifera & Rubiaceae \\
\hline 12 & Gymnema sylvestre & Asclepiadaceae \\
\hline 13 & Hemidesmus indicus & Asclepiadaceae \\
\hline 14 & Icnocarpus frutescens & Apocynaceae \\
\hline 15 & Jatropha gossypifolia & Euphorbiaceae \\
\hline 16 & Lantana camara & Verbenaceae \\
\hline 17 & Phoenix acualis & Arecaceae \\
\hline 18 & Randia uliginosa & Rubiaceae \\
\hline 19 & Ricinus communis & Euphorbiaceae \\
\hline 20 & Rivea hypocrateriformis & Convolvulaceae \\
\hline 21 & Smilax macrophylla & Liliaceae \\
\hline 22 & Streblus asper & Moraceae \\
\hline 23 & Tephrosia purpurea & Papilionaceae \\
\hline 24 & Thespesia lampus & Malvaceae \\
\hline 25 & Trema orientales & Urticaceae \\
\hline 26 & Vangueria spinosa & Rubiaceae \\
\hline 27 & Vitex negundo & Verbenaceae \\
\hline 28 & Woodfordia floribunda & Lythraceae \\
\hline \multicolumn{3}{|l|}{ Herb } \\
\hline 1 & Aerva lanata & Amaranthaceae \\
\hline
\end{tabular}




\begin{tabular}{|c|c|c|}
\hline Sl. No. & Scientific name of the species & Family \\
\hline Tree & & \\
\hline 2 & Ageratum conyzoides & Asteraceae \\
\hline 3 & Alternanthera sessilis & Amaranthaceae \\
\hline 4 & Alysicarpus monilifer & Fabaceae \\
\hline 5 & Amaranthus spinosus & Amaranthaceae \\
\hline 6 & Aristida adscenscionis & Poaceae \\
\hline 7 & Asparagus racemosus & Asperagaceae \\
\hline 8 & Atylosia scarabaeoides & Papilionaceae \\
\hline 9 & Bonnaya brachiata & Scrophulariaceae \\
\hline 10 & Botrychium daucifolium & Ophioglossaceae \\
\hline 11 & Cassia occidentalis & Caesalpiniaceae \\
\hline 12 & Cassia tora & Fabaceae \\
\hline 13 & Celosia argentia & Amaranthaceae \\
\hline 14 & Curculigo orchioides & Amaryllidaceae \\
\hline 15 & Cynodon dactylon & Poaceae \\
\hline 16 & Cyperus rotundus & Cyperaceae \\
\hline 17 & Dactyloctenium aegypticum & Poaceae \\
\hline 18 & Desmodium triflorum & Papilionaceae \\
\hline 19 & Digitaria sanguinalis & Poaceae \\
\hline 20 & Dioscorea alata & Dioscoreaceae \\
\hline 21 & Eichhornia crassipes $(=$ E. speciosa $)$ & Pontederiaceae \\
\hline 22 & Elephantopus scaber & Asteraceae \\
\hline 23 & Eragrostis tenella & Poaceae \\
\hline 24 & Eragrostis uniloides & Poaceae \\
\hline 25 & Euphorbia hirta & Euphorbiaceae \\
\hline 26 & Euphorbia microphylla & Euphorbiaceae \\
\hline 27 & Evolvulus alsenoides & Convolvulaceae \\
\hline 28 & Evolvulus nummularius & Convolvulaceae \\
\hline 29 & Fimbristylis japonicum & Cyperaceae \\
\hline 30 & Flemingia chapper & Fabaceae \\
\hline 31 & Gymnema sylvestre & Asclepiadaceae \\
\hline 32 & Habenaria diphylla & Orchidaceae \\
\hline 33 & Hemidesmus indicus & Asclepiadaceae \\
\hline 34 & Indigofera pulchella & Fabaceae \\
\hline 35 & Ionidium suffruticosum & Violaceae \\
\hline 36 & Leea sp. & Leeaceae \\
\hline 37 & Panicum repens $L$. & Poaceae \\
\hline 38 & Parthenium hysterophorus & Asteraceae \\
\hline 39 & Paspalidium flavidum & Poaceae \\
\hline 40 & Perotis indica $(=P$. latifolia $)$ & Poaceae \\
\hline 41 & Phagmatis karka & Poaceae \\
\hline
\end{tabular}




\begin{tabular}{ccc}
\hline S1. No. & Scientific name of the species & Family \\
\hline Tree & & \\
\hline 42 & Phyllanthus amarus & Euphorbiaceae \\
43 & Phyllanthus niruri & Euphorbiaceae \\
44 & Rivea hypocretaroformis & Convolvulaceae \\
45 & Rungia parviflora & Acanthaceae \\
46 & Scoparia dulcis & Scrophulariaceae \\
47 & Setaria glauca & Poaceae \\
48 & Sida cordifolia & Malvaceae \\
49 & Solanum zylanicum & Solanaceae \\
50 & Spermacoce hispida & Rubiaceae \\
51 & Stephania harnandifolia & Menispermaceae \\
52 & Thysanolaena maxima & Poaceae \\
53 & Trichosanthus sp. & Cucurbitaceae \\
54 & Tridax procumbens & Asteraceae \\
55 & Triumfetta rhomboidea & Tiliaceae \\
56 & Urena lobata & Malvaceae \\
57 & Vernonia cinerea & Asteraceae \\
\hline
\end{tabular}

\subsection{Vegetation in the Buffer Zone}

Buffer zone comes within $10 \mathrm{~km}$ radius of the mine-lease area and it is within Bailadila Reserve Forest and within Dantewada Taluk, Dantewada district of Chhattisgarh. Buffer zone is mostly covered with undulated hilly terrain within 180m-1200m altitude. More than one third of the Buffer zone is within Bailadila RF, Bijapur RF and Palnar PF. But within 10km radius there is no notified Wildlife Sanctuary and National Park. Talperu and Malenger Nadi are passing through the Buffer Zone. There are few nallahs and stream within the buffer area.

The buffer zone has 253 species in total within which 77 are tree species, 72 are shrubs and 81 are herbs. There are also 2 bamboo species, 3 epiphytes, 1 species of insectivorous plant in this ecosystem (Table 4). Number of herb and shrub species is comparatively much less in the buffer zone than the core zone taking the area in to account. The season of study being winter number herbaceous species in general and grasses in particular are ephemerals in these habitat conditions and therefore not possible to identify.

Table 4. List of plant species at buffer area of Kirandul Iron Ore Mine

\begin{tabular}{ccc}
\hline Sl. No. & Scientific name of the species & Family \\
\hline Tree & & \\
\hline 1 & Acacia catechu & Fabaceae \\
2 & Acacia leucophloea & Fabaceae \\
3 & Adina cordifolia & Rubiaceae \\
4 & Aegle mermelos & Rutaceae \\
5 & Alanzium lamarkii & Cornaceae \\
6 & Albizzia lebbek & Fabaceae \\
7 & Albizzia odoratissima & Fabaceae \\
8 & Albizzia procera & Fabaceae \\
9 & Anogeissus latifolia & Combretaceae \\
10 & Anthocephalus cadamba & Rubiaceae \\
\hline
\end{tabular}




\begin{tabular}{|c|c|c|}
\hline Sl. No. & Scientific name of the species & Family \\
\hline \multicolumn{3}{|l|}{ Tree } \\
\hline 11 & Azadirachta indica & Meliaceae \\
\hline 12 & Bassia latifolia & Sapotaceae \\
\hline 13 & Bauhinia acuminate & Fabaceae \\
\hline 14 & Bauhinia malabarica & Fabaceae \\
\hline 15 & Boaswellia serrate & Burseraceae \\
\hline 16 & Bombax ceiba & Malvaceae \\
\hline 17 & Borassus flabellifer & Arecaceae \\
\hline 18 & Bridelia retusa & Euphorbiaceae \\
\hline 19 & Buchanania lanzen & Anacardiaceae \\
\hline 20 & Butea monosperma & Fabaceae \\
\hline 21 & Careya arborea & Myrtaceae \\
\hline 22 & Carryota urens & Arecaceae \\
\hline 23 & Casearia varacca & Samydaceae \\
\hline 24 & Cassia fistula & Fabaceae \\
\hline 25 & Cedrela toona & Meliaceae \\
\hline 26 & Chloroxylon swietenia & Meliaceae \\
\hline 27 & Cliestanthus collinus & Euphorbiaceae \\
\hline 28 & Cochlospermum religiosum & Bixaceae \\
\hline 29 & Dalbergia paniculata & Fabaceae \\
\hline 30 & Dalbergia sisoo & Fabaceae \\
\hline 31 & Dillenia pentagyna & Dilleniaceae \\
\hline 32 & Diospyros melanoxylon & Ebnaceae \\
\hline 33 & Emblica officinales & Euphorbiaceae \\
\hline 34 & Ficus bengalensis & Moraceae \\
\hline 35 & Ficus glomerata & Moraceae \\
\hline 36 & Ficus religiosa & Moraceae \\
\hline 37 & Flacourtia indica & Flacourtiaceae \\
\hline 38 & Gardenia latifolia & Rubiaceae \\
\hline 39 & Gardenia turgid & Rubiaceae \\
\hline 40 & Garuga pinnata & Burseraceae \\
\hline 41 & Gmelina arborea & Verbinaceae \\
\hline 42 & Grewia tiliaefolia & Tiliaceae \\
\hline 43 & Hardwickia binate & Fabaceae \\
\hline 44 & Ixora arborea & Rubiaceae \\
\hline 45 & Kydia calycina & Malvaceae \\
\hline 46 & Lagerstromea perviflora & Lythraceae \\
\hline 47 & Lannea coromandelica & Anacardiaceae \\
\hline 48 & Mallotus phillipensis & Euphorbiaceae \\
\hline 49 & Mitragyna parviflora & Rubiaceae \\
\hline 50 & Morinda tinctoria & Rubiaceae \\
\hline
\end{tabular}




\begin{tabular}{|c|c|c|}
\hline Sl. No. & Scientific name of the species & Family \\
\hline \multicolumn{3}{|l|}{ Tree } \\
\hline 51 & Ougeinia oogeinensis & Fabaceae \\
\hline 52 & Phoenix sylvestris & Arecaceae \\
\hline 53 & Polyalthia cerasoides & Annonaceae \\
\hline 54 & Pongamia pinnata & Fabaceae \\
\hline 55 & Pterocarpus marsupium & Fabaceae \\
\hline 56 & Randia uliginosa & Rubiaceae \\
\hline 57 & Saccopetalum tomentosum & Annonaceae \\
\hline 58 & Schrebera swietenioides & Olieaceae \\
\hline 59 & Semecarpus anacardium & Anacardiaceae \\
\hline 60 & Sleichera oliosa & Sapindaceae \\
\hline 61 & Solanum verbassifolium & Solanaceae \\
\hline 62 & Soymida febrifuga & Meliaceae \\
\hline 63 & Sterculia urens & Sterculaceae \\
\hline 64 & Sterospermum personatum & Bignoniaceae \\
\hline 65 & Sterospermum suaveolens & Bignoniaceae \\
\hline 66 & Strychnos nux-vomica & Loganiaceae \\
\hline 67 & Syzizium cumini & Myrtaceae \\
\hline 68 & Tamarindus indica & Fabaceae \\
\hline 69 & Tectona grandis & Verbinaceae \\
\hline 70 & Terminalia alata & Combretaceae \\
\hline 71 & Terminalia belerica & Combretaceae \\
\hline 72 & Terminalia tomentosa & Combretaceae \\
\hline 73 & Termmalia arjuna & Combretaceae \\
\hline 74 & Trema orientalis & Urticaceae \\
\hline 75 & Wrightia tinctoria & Apocynaceae \\
\hline 76 & Xylia xylocarpa & Fabaceae \\
\hline 77 & Zizyphus mauritiana & Rhamnaceae \\
\hline \multicolumn{3}{|l|}{ Shrub } \\
\hline 1 & Abrus precatorius & Fabaceae \\
\hline 2 & Acacia caesia & Fabaceae \\
\hline 3 & Acacia pennata & Fabaceae \\
\hline 4 & Achyranths aspera & Amaranthaceae \\
\hline 5 & Alangium salvifoloum & Cornaceae \\
\hline 6 & Andrographis paniculata & Acanthaceae \\
\hline 7 & Antidesma diandrum & Euphorbiaceae \\
\hline 8 & Aristolochia indica & Aristolochiaceae \\
\hline 9 & Asparagus racemosus & Liliaceae \\
\hline 10 & Bambusa arundinacea & Poaceae \\
\hline 11 & Bauhinia vahlii & Fabaceae \\
\hline 12 & Butea superba & Fabaceae \\
\hline
\end{tabular}




\begin{tabular}{|c|c|c|}
\hline Sl. No. & Scientific name of the species & Family \\
\hline \multicolumn{3}{|l|}{ Tree } \\
\hline 13 & Caesalpinia bonducella & Caesalpiniaceae \\
\hline 14 & Calotropis procera & Asclepiadaceae \\
\hline 15 & Capparis spinosa & Capparidaceae \\
\hline 16 & Carissa spinarum & Apocynaceae \\
\hline 17 & Casiarea varacca & Samydaceae \\
\hline 18 & Catasibee spinosa & Flacourtiaceae \\
\hline 19 & Celastrus paniculata & Celastraceae \\
\hline 20 & Clerodendron serratum & Verbinaceae \\
\hline 21 & Coccinia grandis (= Cephalandra indica) & Cucurbitaceae \\
\hline 22 & Combretum roxburghii & Combretceae \\
\hline 23 & Cryptolepis buchanani & Apocynaceae \\
\hline 24 & Cucuma aromtica & Zingiberaceae \\
\hline 25 & Dendrocalamus strictus & Poaceae \\
\hline 26 & Desmodium laxiflorum & Fabaceae \\
\hline 27 & Dioscorea bulbifera & Dioscoreaceae \\
\hline 28 & Dioscorea floribunda & Dioscoreaceae \\
\hline 29 & Dioscoria alata & Dioscoriaceae \\
\hline 30 & Dioscoria belophylla & Dioscoriaceae \\
\hline 31 & Dioscoria pentaphylla & Dioscoriaceae \\
\hline 32 & Embilia robusta & Myrsinaceae \\
\hline 33 & Eranthemum pulchellum & Acanthaceae \\
\hline 34 & Eulaliopsis binate & Poaceae \\
\hline 35 & Flacourtia indica & Flacourtiaceae \\
\hline 36 & Flacourtia ramontchi & Flacourtiaceae \\
\hline 37 & Gardenia gummifera & Rubiaceae \\
\hline 38 & Grewia hirsute & Tiliaceae \\
\hline 39 & Gymnema sylvestre & Asclepiadaceae \\
\hline 40 & Helisteris isora & Sterculaceae \\
\hline 41 & Hemidesmus indicus & Asclepiadaceae \\
\hline 42 & Hibiscus ficulneus & Malvaceae \\
\hline 43 & Holarrhena antidysenterica & Apocynaceae \\
\hline 44 & Icnocarpus frutescens & Apocynaceae \\
\hline 45 & Indigofera arborea & Fabaceae \\
\hline 46 & Indigofera tinctoria & Fabaceae \\
\hline 47 & Jatropha gossypifolia & Euphorbiaceae \\
\hline 48 & Lantana camara & Verbenaceae \\
\hline 49 & Leea macrophylla & Vitaceae \\
\hline 50 & Lygodium japonicum & Schizaeaceae \\
\hline 51 & Mahonia semialata & Fabaceae \\
\hline 52 & Mukuna puruita & Fabaceae \\
\hline
\end{tabular}




\begin{tabular}{|c|c|c|}
\hline Sl. No. & Scientific name of the species & Family \\
\hline \multicolumn{3}{|l|}{ Tree } \\
\hline 53 & Nyctanthus arbortris-tis & Oleaceae \\
\hline 54 & Oxytenanthera nigrocilliat & Poaceae \\
\hline 55 & Petalidium barlerioides & Acanthaceae \\
\hline 56 & Phoenix acualis & Arecaceae \\
\hline 57 & Randia uliginosa & Rubiaceae \\
\hline 58 & Ricinus communis & Euphorbiaceae \\
\hline 59 & Rivea hypocrateriformis & Convolvulaceae \\
\hline 60 & Smilax macrophylla & Liliaceae \\
\hline 61 & Stephania harnadifolia & Apocyanceae \\
\hline 62 & Streblus asper & Moraceae \\
\hline 63 & Swertia angustifolia & Acanthaceae \\
\hline 64 & Tephrosia purpurea & Papilionaceae \\
\hline 65 & Thespesia lampus & Malvaceae \\
\hline 66 & Trema orientales & Urticaceae \\
\hline 67 & Vangueria spinosa & Rubiaceae \\
\hline 68 & Ventilago denticulate & Rhamnaceae \\
\hline 69 & Vitex negundo & Verbinaceae \\
\hline 70 & Woodfordia floribunda & Lythraceae \\
\hline 71 & Zizyphus oenoplia & Rhamnaceae \\
\hline 72 & Zizyphus rugosa & Rhamnaceae \\
\hline \multicolumn{3}{|l|}{ Herb } \\
\hline 1 & Aerva lanata & Amaranthaceae \\
\hline 2 & Ageratum conyzoides & Asteraceae \\
\hline 3 & Alocasia macrorhiza $(=A$. indica $)$ & Araceae \\
\hline 4 & Alternanthera sessilis & Amaranthaceae \\
\hline 5 & Alysicarpus monilifer & Fabaceae \\
\hline 6 & Amaranthus spinosus & Amaranthaceae \\
\hline 7 & Aristida adscenscionis & Poaceae \\
\hline 8 & Asparagus racemosus & Asperagaceae \\
\hline 9 & Atylosia indica & Papilionaceae \\
\hline 10 & Atylosia scarabaeoides & Papilionaceae \\
\hline 11 & Barleria prionitis & Acanthaceae \\
\hline 12 & Bonnaya brachiate & Scrophulariaceae \\
\hline 13 & Botrychium daucifolium & Ophioglossaceae \\
\hline 14 & Cassia occidentalis & Caesalpiniaceae \\
\hline 15 & Cassia tora & Fabaceae \\
\hline 16 & Celosia argentia & Amaranthaceae \\
\hline 17 & Crinum asiaticum & Liliaceae \\
\hline 18 & Curculigo orchioides & Amaryllidaceae \\
\hline 19 & Curcuma amada & Zinziberaceae \\
\hline
\end{tabular}




\begin{tabular}{|c|c|c|}
\hline Sl. No. & Scientific name of the species & Family \\
\hline Tree & & \\
\hline 20 & Curcuma aromatic & Zingiberaceae \\
\hline 21 & Cuscuta reflexa & Convolvulaceae \\
\hline 22 & Cynodon dactylon & Poaceae \\
\hline 23 & Cyperus rotundus & Cyperaceae \\
\hline 24 & Dactyloctenium aegypticum & Poaceae \\
\hline 25 & Dendrofthoe fulcata & Loranthaceae \\
\hline 26 & Desmodium triflorum & Papilionaceae \\
\hline 27 & Digitaria sanguinalis & Poaceae \\
\hline 28 & Dioscorea alata & Dioscoreaceae \\
\hline 29 & Eclipta prostrate & Asteraceae \\
\hline 30 & Eichhornia crassipes $(=$ E. speciosa) & Pontederiaceae \\
\hline 31 & Elephantopus scaber & Asteraceae \\
\hline 32 & Eleusine coarcana & Poaceae \\
\hline 33 & Eleusine indica & Poaceae \\
\hline 34 & Eragrostis tenella & Poaceae \\
\hline 35 & Eragrostis uniloides & Poaceae \\
\hline 36 & Eulalipsis binate & Poaceae \\
\hline 37 & Euphorbia hirta & Euphorbiaceae \\
\hline 38 & Euphorbia microphylla & Euphorbiaceae \\
\hline 39 & Evolvulus alsenoides & Convolvulaceae \\
\hline 40 & Evolvulus nummularius & Convolvulaceae \\
\hline 41 & Fimbristylis japonicum & Cyperaceae \\
\hline 42 & Habenaria diphylla & Orchidaceae \\
\hline 43 & Hemidesmus indicus & Asclepiadaceae \\
\hline 44 & Heteropogon contortus & Poaceae \\
\hline 45 & Imperata cylindrical & Poaceae \\
\hline 46 & Indigofera pulchella & Fabaceae \\
\hline 47 & Ionidium suffruticosum & Violaceae \\
\hline 48 & Leea sp. & Leeaceae \\
\hline 49 & Lygodium japonicum & Schizaeaceae \\
\hline 50 & Mukuna prurita & Fabaceae \\
\hline 51 & Ocimum canum & Lamiaceae \\
\hline 52 & Panicum milare & Poaceae \\
\hline 53 & Panicum repens & Poaceae \\
\hline 54 & Parthenium hysterophorus & Asteraceae \\
\hline 55 & Paspalidium flavidum & Poaceae \\
\hline 56 & Paspalum scrobiculatum & Poaceae \\
\hline 57 & Perotis indica $(=P$. latifolia $)$ & Poaceae \\
\hline 58 & Phagmatis karka & Poaceae \\
\hline 59 & Phyllanthus amaru & Euphorbiaceae \\
\hline
\end{tabular}




\begin{tabular}{|c|c|c|}
\hline Sl. No. & Scientific name of the species & Family \\
\hline \multicolumn{3}{|l|}{ Tree } \\
\hline 60 & Phyllanthus niruri & Euphorbiaceae \\
\hline 61 & Rivea hypocretaroformis & Convolvulaceae \\
\hline 62 & Rungia parviflora & Acanthaceae \\
\hline 63 & Saccharum spontaneum & Poaceae \\
\hline 64 & Scoparia dulcis & Scrophulariaceae \\
\hline 65 & Setaria glauca & Poaceae \\
\hline 66 & Setaria $s p$ & Poaceae \\
\hline 67 & Sida cordifolia & Malvaceae \\
\hline 68 & Sida cordata & Malvaceae \\
\hline 69 & Sida rhomboidea & Malvaceae \\
\hline 70 & Solanum zylanicum & Solanaceae \\
\hline 71 & Spermacoce hispida & Rubiaceae \\
\hline 72 & Stephania harnandifolia & Menispermaceae \\
\hline 73 & Thysanolaena maxima & Poaceae \\
\hline 74 & Trichosanthus sp. & Cucurbitaceae \\
\hline 75 & Tridax procumbens & Asteraceae \\
\hline 76 & Triumfetta rhomboidea & Tiliaceae \\
\hline 77 & Urena lobata & Malvaceae \\
\hline 78 & Vernonia cinerea & Asteraceae \\
\hline 79 & Vetiveria zizanoides & Poaceae \\
\hline 80 & Viscum articulatum & Loranthaceae \\
\hline 81 & Zornia diphylla & Papilionaceae \\
\hline \multicolumn{3}{|l|}{ Epiphytes } \\
\hline 1 & Cuscuta roxburghii & Convolvulaceae \\
\hline 2 & Viscum articulatum & Viscaceae \\
\hline 3 & Vanda roxburghii & Loranthaceae \\
\hline \multicolumn{3}{|l|}{ Bamboos } \\
\hline 1 & Dendrocalamus strictus & Poaceae \\
\hline 2 & Bambusa arundinacea & Poaceae \\
\hline \multicolumn{3}{|c|}{ Insectivorous plant } \\
\hline 1 & Drocera burmanii & Droceraceae \\
\hline
\end{tabular}

The diversity index (Table 5) in the tree level (2.10) is much more in the buffer zone in comparison to core zone (1.44). However, in our study, the species diversity index is lower than compared to other studies done at Eastern Ghats (Sahu et al., 2007; Reddy et al., 2008; Ganguli et al., 2016). Anthropogenic activity within forest area seems to be low in the tree layer as observed from the count of cut off stumps. Canopy cover in most places of the forest area in this zone is within $40-70 \%$ which is known to be dense forest as per the FSI classification. 
Table 5. Phytosociological parameters of core and buffer zones of Kirandul complex

\begin{tabular}{cccc}
\hline S1. No. & Indices & Core Zone & Buffer Zone \\
\hline 1 & Canopy Cover $(\%)$ & $0 \%-10 \%(40 \%$ in one site $)$ & $10 \%-40 \%$ and $40 \%-70 \%$ \\
\hline \multirow{3}{*}{2} & Diversity Index & & \\
& Tree Level & 1.44 & 2.10 \\
& Shrub level & 1.75 & 2.05 \\
& Herb level & 1.13 & 1.49 \\
\hline \multirow{3}{*}{3} & Dominance Index & & \\
& Tree level & 0.36 & 0.27 \\
& Shrub level & 0.42 & 0.13 \\
& Herb level & 0.52 & 0.22 \\
\hline
\end{tabular}

Dominance index in the tree level of the buffer zone is only 0.27 which is much lower to 0.36 in comparison to core zone. This signifies that the tree layer in the buffer zone is shared by many species rather than a few ones which is a tendency towards mixed forest type rather than dominance of few tree species. Dominancy of single species is often attributed to niche diversification, disease, species competition and grazing (Whittaker \& Levin, 1977; Harper, 1977). It is also observed that within the buffer zone there are few important species like Bauhinia malabarica, Cedrela toona Dalbergia paniculata, Croton oblongifolia, Shorea robusta, and Annona squoamosa which are considered to be prominent forest species of central India. The availability of some of these species is not very frequent in the core zone. Species like Borassus flabellifer, Azadirachta indica, Terminalia tomentosa, Eugenia jambolana, Ficus glomerata, Terminalia arjuna, Diospyros montana, and Mangifera indica share the tree canopy layer in the non-forest area of the buffer zone. Diversity in the tree level in the non-forest areas is further enhanced by the availability of non-forest species like Mangifera indica, and Acacia auriculiformis, etc. Shrub species like Lantana camara and Eupatorium odoratum, Parthenium sp are also available in this region which is considered to be the invasive species in Indian forests as well as non-forest areas. These invasive species are also very frequently available in the core area. Availability of these species in the buffer zone signifies that there is considerable anthropogenic intervention in the ecosystem which has resulted in alteration of species composition of the core as well as buffer zone which is similar to the studies on impact of invasive species on forests (Gordon, 1998; Sanders et al., 2003; Charles \& Dukes, 2007; Capers et al., 2009; Devine \& Fei, 2011; Priyanka \& Joshi, 2013).

There may be less extraction of forest resources form the buffer zone due to its remoteness but long term impact of human habitation and planting of domesticated species and exotic species like teak and Eucalyptus sp certainly have a negative impact on the ecosystem. This is why initiative on the part of NMDC in developing positive attitude towards conserving the forest resources in the buffer zone is suggested. Habitat development, therefore, cannot confine within the efforts of plantation, water body creation or soil conservation only. It also will include developing participatory conservation approach taking the villagers of the buffer as well as fringe area in to confidence. There is a clear negative relationship between the diversity and dominance indices in both core and buffer zone. In the buffer zone this relationship is more evident because of its pristine nature.

\subsection{Faunal Study}

The State of Chhattisgarh falls under the Deccan Bio-geographical Zone (Rodgers et al., 2000). Of its forests, 11\% are under the Protected Area Network. During the study period around 208 species belongs to 10 Faunal Groups recorded from the Core and Buffer Areas of Kirandul Complex Iron Ore Mines study sites, in that 18 species recorded belongs to Mollusca; 1 species of Crustacean; 19 species of Odonata; 41 species of Lepidoptera; 3 species of Hymenoptera; 8 species of Fishes; 4 species of Amphibians; 7 species of Reptiles; 92 species of Birds and 15 species of Mammals. Out of total 208 species recorded, 34 species (i.e., 1 species of Lepidoptera, 21 species of Birds and 12 species of Mammals) are listed in different Schedules of Indian Wildlife (Protection) Act, 1972 (Table 6). The locatrion map of different species spotted in the study area is shown in Figure 3. 
Table 6. Details of Fauna recorded at Kirandul Iron Ore Mine (Core and Buffer Area)

\begin{tabular}{|c|c|c|c|c|c|}
\hline \multirow[t]{2}{*}{ Sl. No. } & \multirow[t]{2}{*}{ Species } & \multicolumn{4}{|c|}{ Kirandul Complex Iron Ore Mines } \\
\hline & & Deposit 14 & $\begin{array}{l}\text { Deposit } \\
14 \mathrm{NMZ}\end{array}$ & $\begin{array}{c}\text { Deposit } \\
11 \mathrm{~B}\end{array}$ & $\begin{array}{c}\text { Buffer } \\
\text { Area }\end{array}$ \\
\hline \multicolumn{6}{|c|}{ (A) Mollusca } \\
\hline 1 & Bellamya bengalensis form typica & - & - & - & + \\
\hline 2 & Bellamya crassa & - & - & - & + \\
\hline 3 & Bellamya dissimilis & - & - & - & + \\
\hline 4 & Bithynia (Digoniostoma) cerameopoma & - & - & - & + \\
\hline 5 & Bithynia (Digoniostoma) pulchella & - & - & - & + \\
\hline 6 & Melanoides tuberculata & - & - & - & + \\
\hline 7 & Tarebia lineata & - & - & - & + \\
\hline 8 & $\begin{array}{c}\text { Lymnaea (Pseudosuccinea) acuminata form } \\
\text { typica and form chlamys }\end{array}$ & - & - & - & + \\
\hline 9 & Lymnaea (Pseudosuccinea) luteola form typica & - & - & - & + \\
\hline 10 & Lamellidens corrianus & - & - & - & + \\
\hline 11 & Lamellidens marginalis & - & - & - & + \\
\hline 12 & Corbicula striatella & - & - & - & + \\
\hline 13 & Cyclophorus (Litostylus) polynema & - & - & - & + \\
\hline 14 & Edouardia orbus & - & - & - & + \\
\hline 15 & Pterocylus rupestris & - & - & - & + \\
\hline 16 & Ariophanta laidlayana & - & + & - & + \\
\hline 17 & Hemiplecta basileus & - & - & - & + \\
\hline 18 & Macrochlamys indica & + & - & - & + \\
\hline \multicolumn{6}{|c|}{ (B) Crustacean (Crab) } \\
\hline 19 & Brachytelphusa jaquemontii & - & - & - & + \\
\hline \multicolumn{6}{|c|}{ (C) Odonata (Damsel \& Dragonflies) } \\
\hline 20 & Ceriagrion coromandelianum & - & - & - & + \\
\hline 21 & Ischnura aurora & - & - & - & + \\
\hline 22 & Pseudagrion rubriceps & - & - & - & + \\
\hline 23 & Ictinogomphus rapax & - & - & - & + \\
\hline 24 & Anax immaculifrons & - & - & - & + \\
\hline 25 & Acisoma panorpoides & - & - & - & + \\
\hline 26 & Brachythemis contaminata & - & - & - & + \\
\hline 27 & Crocothemis servilia & + & - & + & + \\
\hline 28 & Diplacodes trivalis & - & + & - & + \\
\hline 29 & Orthetrum glaucum & - & - & - & + \\
\hline 30 & Orthetrum pruinosum & + & - & - & + \\
\hline 31 & Orthetrum sabina & - & - & + & + \\
\hline 32 & Orthetrum triangulare & - & - & - & + \\
\hline 33 & Palpopleura sexmaculata & - & - & - & + \\
\hline 34 & Pantala flavescens & + & + & + & + \\
\hline
\end{tabular}




\begin{tabular}{|c|c|c|c|c|c|}
\hline \multirow[t]{2}{*}{ Sl. No. } & \multirow[t]{2}{*}{ Species } & \multicolumn{4}{|c|}{ Kirandul Complex Iron Ore Mines } \\
\hline & & Deposit 14 & $\begin{array}{l}\text { Deposit } \\
\text { 14NMZ }\end{array}$ & $\begin{array}{c}\text { Deposit } \\
\text { 11B }\end{array}$ & $\begin{array}{c}\text { Buffer } \\
\text { Area }\end{array}$ \\
\hline 35 & Tramea virgina & - & - & - & + \\
\hline 36 & Trithemis aurora & - & - & - & + \\
\hline 37 & Trithemis festiva & - & + & - & + \\
\hline 38 & Trithemis pallidinervis & - & - & - & + \\
\hline \multicolumn{6}{|c|}{ (D) Lepidoptera (Butterflies) } \\
\hline 39 & Graphium agamemnon & - & - & - & + \\
\hline 40 & Papilio polytes & - & + & - & + \\
\hline 41 & Papilio demoleus & - & - & - & + \\
\hline 42 & Atrophaneura aristolochiae & - & - & - & + \\
\hline 43 & Eurema hecabe & + & + & - & + \\
\hline 44 & Catopsilia pomona & - & - & - & + \\
\hline 45 & Catopsilia pyranthe & - & + & + & + \\
\hline 46 & Colotis danae & - & - & - & + \\
\hline 47 & Ixias marianne & + & - & - & + \\
\hline 48 & Ixias pyrene & - & - & - & + \\
\hline 49 & Pieris brassicae & - & - & - & + \\
\hline 50 & Pieris canidia & - & - & - & + \\
\hline 51 & Cepora nerissa & - & + & - & + \\
\hline 52 & Delias eucharis & + & - & - & + \\
\hline 53 & Belenois aurota & - & - & - & + \\
\hline 54 & Castalius rosimon & - & - & - & + \\
\hline 55 & Catochrysops strabo & - & - & - & + \\
\hline 56 & Pseudozizeeria maha & + & + & - & + \\
\hline 57 & Tirumala limniace & - & - & - & + \\
\hline 58 & Danaus genutia & - & + & - & + \\
\hline 59 & Danaus chrysippus & + & + & - & + \\
\hline 60 & Euploea core & - & - & - & + \\
\hline 61 & Polyura athamas & - & - & - & + \\
\hline 62 & Melanitis leda & - & - & - & + \\
\hline 63 & Acraea violae & - & - & - & + \\
\hline 64 & Argyreus hyperbius & - & - & - & + \\
\hline 65 & Phalanta phalantha & - & - & - & + \\
\hline 66 & Moduza procris & - & - & - & + \\
\hline 67 & Athyma perius & - & - & - & + \\
\hline 68 & Euthalia nais & - & - & - & + \\
\hline 69 & Tanaecia lepidea & - & - & - & + \\
\hline 70 & Cyrestis thyodamas & - & - & - & + \\
\hline 71 & Ariadne ariadne & - & - & - & + \\
\hline 72 & Junonia orrithiya & - & - & - & + \\
\hline
\end{tabular}




\begin{tabular}{cccccc}
\hline Sl. No. & Species & \multicolumn{4}{c}{ Kirandul Complex Iron Ore Mines } \\
\hline & & Deposit 14 & Deposit & Deposit & Buffer \\
& & - & - & - & + \\
\hline 73 & Junonia hierta & - & + & + & + \\
74 & Junonia iphita & - & - & - & + \\
75 & Junonia atlites & - & - & - & + \\
76 & Junonia almana & + & + & + & + \\
77 & Junonia lemonias & - & - & - & + \\
78 & Hypolimnas misippus & - & - & - & + \\
79 & Kallima inachus & & & &
\end{tabular}

(E) Hymenoptera (Bees and Wasp)

\begin{tabular}{lccccc}
\hline 80 & Apis (Megapis) dorsata dorsata & + & - & - & + \\
81 & Ropalidia brevita & - & - & - & + \\
82 & Delta pyriforme pyriforme & - & - & - & + \\
\hline
\end{tabular}

(F) Pisces (Fishes)

\begin{tabular}{lclllc}
\hline 83 & Channa gachua & - & - & - & + \\
84 & Danio dangila & - & - & - & + \\
85 & Danio rerio & - & - & - & + \\
86 & Garra mullya & - & - & - & + \\
87 & Pethia conchonius & - & - & - & + \\
88 & Puntius amphibius & - & - & - & + \\
89 & Rasbora daniconius & - & - & - & + \\
90 & Schistura dayi & - & - & - & + \\
\hline
\end{tabular}

\begin{tabular}{cccccc}
\hline (G) Amphibians (Toad and Frogs) & & & & \\
\hline 91 & Duttaphrynus melanostictus & - & - & - & + \\
92 & Euphlyctis cyanophlyctis & - & - & - & + \\
93 & Fejervarya syhadrensis & - & - & - & + \\
94 & Fejervarya orissaensis & - & - & - & + \\
\hline
\end{tabular}

(H) Reptiles (Lizards, Skinks and Snakes)

\begin{tabular}{cccccc}
\hline 95 & Calotes versicolor & + & + & + & + \\
96 & Psammophilus dorsalis & + & - & + & + \\
97 & Hemidactylus brooki & - & - & - & + \\
98 & Lygosoma punctata & - & - & - & + \\
99 & Mabuya macularia & - & - & - & + \\
100 & Echis carinatus & - & - & - & + \\
101 & Lycodon aulicus & + & - & + & + \\
\hline (I) Aves (Birds) & & & & & \\
\hline 102 & Gallus gallus & - & - & - & + \\
103 & Pavo cristatus & - & - & - & + \\
104 & Hemicircus canente & - & - & - & + \\
105 & Dendrocopos nanus & - & - & - & + \\
106 & Dendrocopos canicapillus & - & - & - & + \\
\hline
\end{tabular}




\begin{tabular}{|c|c|c|c|c|c|}
\hline \multirow[t]{2}{*}{ Sl. No. } & \multirow[t]{2}{*}{ Species } & \multicolumn{4}{|c|}{ Kirandul Complex Iron Ore Mines } \\
\hline & & Deposit 14 & $\begin{array}{l}\text { Deposit } \\
14 \mathrm{NMZ}\end{array}$ & $\begin{array}{c}\text { Deposit } \\
\text { 11B }\end{array}$ & $\begin{array}{c}\text { Buffer } \\
\text { Area }\end{array}$ \\
\hline 107 & Dinopium benghalense & - & + & - & + \\
\hline 108 & Megalaima lineata & - & - & - & + \\
\hline 109 & Megalaima asiatica & - & - & - & + \\
\hline 110 & Megalaima haemacephala & - & - & - & + \\
\hline 111 & Coracius benghalensis & + & + & + & + \\
\hline 112 & Halcyon smyrensis & - & - & - & + \\
\hline 113 & Nyctyornis athertoni & - & - & - & + \\
\hline 114 & Merops orientalis & - & + & + & + \\
\hline 115 & Merops leschenaulti & - & - & - & + \\
\hline 116 & Hierococcyx varius & - & - & - & + \\
\hline 117 & Phaenicophaeus tristis & - & - & - & + \\
\hline 118 & Centropus sinensis & + & - & - & + \\
\hline 119 & Psittacula cyanocephala & - & - & - & + \\
\hline 120 & Cypsiurus balasiensis & - & + & - & + \\
\hline 121 & Columba livia & - & + & + & + \\
\hline 122 & Streptopelia chinensis & + & - & - & + \\
\hline 123 & Actitis hypoleucos & - & - & - & + \\
\hline 124 & Vanellus malabaricus & - & - & - & + \\
\hline 125 & Vanellus cinereus & - & + & - & + \\
\hline 126 & Vanellus indicus & - & - & & + \\
\hline 127 & Milvus migrans & - & - & - & + \\
\hline 128 & Spilornis cheela & - & - & - & + \\
\hline 129 & Accipiter badius & - & - & - & + \\
\hline 130 & Spizaetus cirrhatus & - & - & - & + \\
\hline 131 & Falco tinnunculus & + & + & - & + \\
\hline 132 & Phalacrocorax niger & - & - & - & + \\
\hline 133 & Egretta garzetta & - & - & - & + \\
\hline 134 & Mesophoyx intermedia & - & - & - & + \\
\hline 135 & Bubulcus ibis & - & + & + & + \\
\hline 136 & Ardeola grayii & - & - & - & + \\
\hline 137 & Pseudibis papillosa & - & - & - & + \\
\hline 138 & Pitta brachyura & + & + & - & + \\
\hline 139 & Chloropsis cochinchinensis & - & - & - & + \\
\hline 140 & Lanius cristatus & - & - & - & + \\
\hline 141 & Lanius schach tricolor & - & - & - & + \\
\hline 142 & Dendrocitta vagabunda & - & - & - & + \\
\hline 143 & Corvus splendens & + & + & - & + \\
\hline 144 & Oriolus tenuirostris & - & - & - & + \\
\hline 145 & Oriolus xanthornus & - & - & - & + \\
\hline
\end{tabular}




\begin{tabular}{|c|c|c|c|c|c|}
\hline \multirow[t]{2}{*}{ Sl. No. } & \multirow[t]{2}{*}{ Species } & \multicolumn{4}{|c|}{ Kirandul Complex Iron Ore Mines } \\
\hline & & Deposit 14 & $\begin{array}{l}\text { Deposit } \\
14 \mathrm{NMZ}\end{array}$ & $\begin{array}{c}\text { Deposit } \\
\text { 11B }\end{array}$ & $\begin{array}{c}\text { Buffer } \\
\text { Area }\end{array}$ \\
\hline 146 & Coracina melaschistos & - & - & - & + \\
\hline 147 & Pericrocotus divaricatus & - & - & - & + \\
\hline 148 & Pericrocotus erythropygius & - & - & - & + \\
\hline 149 & Pericrocotus flammeus & + & - & - & + \\
\hline 150 & Rhipidura aureola & - & - & - & + \\
\hline 151 & Dicrurus macrocercus & - & - & - & + \\
\hline 152 & Dicrurus caerulescens & - & - & - & + \\
\hline 153 & Dicrurus aeneus & - & + & - & + \\
\hline 154 & Dicrurus paradiseus & - & - & - & + \\
\hline 155 & Hypothymis azurea & - & - & - & + \\
\hline 156 & Aegithina tiphia & - & - & - & + \\
\hline 157 & Monticola solitarius & - & - & - & + \\
\hline 158 & Monticola cinclorhynchus & + & - & - & + \\
\hline 159 & Zoothera citrina cyanotus & - & - & - & + \\
\hline 160 & Zoothera dauma & - & - & - & + \\
\hline 161 & Eumyias thalassina & - & - & - & + \\
\hline 162 & Cyornis poliogenys & - & - & - & + \\
\hline 163 & Copsychus saularis & - & - & - & + \\
\hline 164 & Saxicoloides fulicata & + & - & - & + \\
\hline 165 & Phoenicurus ochruros & - & - & - & + \\
\hline 166 & Sturnus contra & - & - & - & + \\
\hline 167 & Acridotheres tristis & - & - & - & + \\
\hline 168 & Sitta castanea & - & + & - & + \\
\hline 169 & Sitta frontalis & - & - & - & + \\
\hline 170 & Parus xanthogenys & - & - & - & + \\
\hline 171 & Hirundo rustica & + & - & - & + \\
\hline 172 & Pycnonotus melanicterus & - & - & - & + \\
\hline 173 & Pycnonotus jocosus & - & - & - & + \\
\hline 174 & Pycnonotus cafer & - & - & - & + \\
\hline 175 & Prinia socialis & - & - & - & + \\
\hline 176 & $\begin{array}{c}\text { Zosterops } \\
\text { palpebrosus }\end{array}$ & - & - & - & + \\
\hline 177 & Orthotomus sutorius & - & - & - & + \\
\hline 178 & Phylloscopus colybita & - & + & - & + \\
\hline 179 & Phylloscopus trochiloides & - & - & - & + \\
\hline 180 & Pomatorhinus horsfieldii & - & - & - & + \\
\hline 181 & Pellorneum ruficeps & - & - & - & + \\
\hline 182 & Chrysomma sinense & + & - & - & + \\
\hline 183 & Turdoides striatus & - & - & - & + \\
\hline
\end{tabular}




\begin{tabular}{|c|c|c|c|c|c|}
\hline \multirow[t]{2}{*}{ Sl. No. } & \multirow[t]{2}{*}{ Species } & \multicolumn{4}{|c|}{ Kirandul Complex Iron Ore Mines } \\
\hline & & Deposit 14 & $\begin{array}{l}\text { Deposit } \\
\text { 14NMZ }\end{array}$ & $\begin{array}{c}\text { Deposit } \\
\text { 11B }\end{array}$ & $\begin{array}{c}\text { Buffer } \\
\text { Area }\end{array}$ \\
\hline 184 & Turdoides affinis & - & - & - & + \\
\hline 185 & Dicaeum erythrorynchos & - & - & - & + \\
\hline 186 & Nectarinia asiatica & - & - & - & + \\
\hline 187 & Passer domesticus & + & + & + & + \\
\hline 188 & Motacilla flava & - & - & - & + \\
\hline 189 & Motacilla cinerea & - & - & - & + \\
\hline 190 & Anthus rufulus & - & + & - & + \\
\hline 191 & Anthus campestris & - & - & - & + \\
\hline 192 & Lonchura striata & - & - & - & + \\
\hline 193 & Lonchura punctulata & + & - & - & + \\
\hline \multicolumn{6}{|c|}{ (J) Mammals } \\
\hline 194 & Macaca mulatta & + & + & + & + \\
\hline 195 & Semnopithecus entellus & + & + & + & + \\
\hline 196 & Muntiacus muntjak & - & - & - & + \\
\hline 197 & Sus scrofa & - & - & - & + \\
\hline 198 & Melursus ursinus & + & + & + & + \\
\hline 199 & Canis aureus & - & + & - & + \\
\hline 200 & Vulpes bengalensis & - & - & - & + \\
\hline 201 & ${ }^{*}$ Panthera tigris & - & - & - & + \\
\hline 202 & Panthera pardus & - & - & - & + \\
\hline 203 & Harpestes edwardsii & + & + & + & + \\
\hline 204 & Lepus nigricollis & - & + & + & + \\
\hline 205 & Hystrix indica & + & - & - & + \\
\hline 206 & Ratufa indica & + & + & - & + \\
\hline 207 & Funambulus pennantii & + & + & + & + \\
\hline 208 & Pteropus giganteus & - & - & - & + \\
\hline
\end{tabular}

Discription: Where (+) indicates Presence and (-) indicates Absence of the species in the study area. 


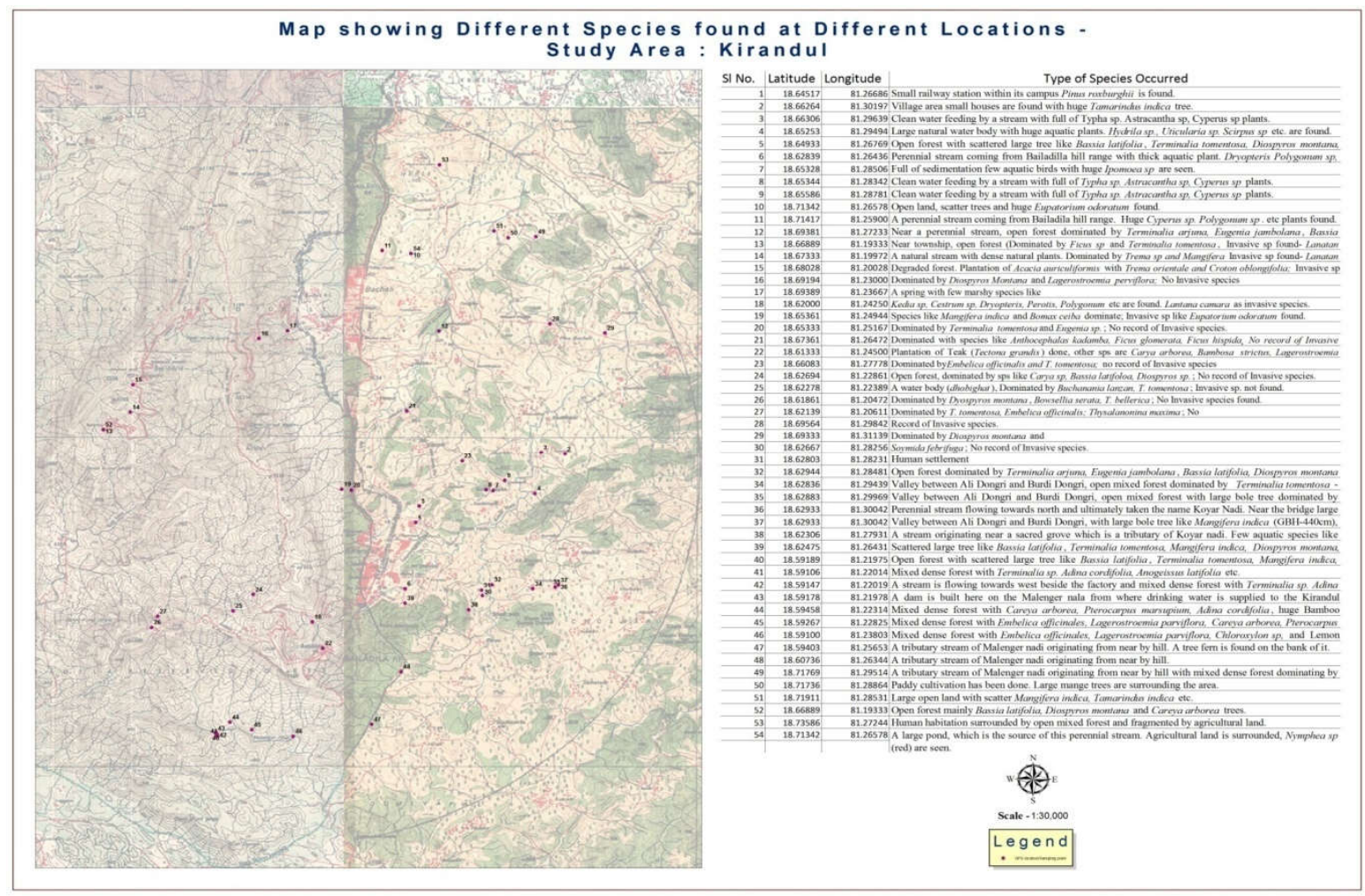

Figure 3. Map showing different faunal species found at different locations of the study area

\subsection{Major Threats to Biodiversity}

Large scale loss of biodiversity has been mainly caused by anthropogenic activities like habitat loss, degradation, fragmentation, biotic interference, grazing, demand for timber, fuel wood, pollution and introduction of exotic species, etc. Due to large scale mining during last few decades in Bailadila forest area the above mentioned causes has aggravated by few folds. Some of these factors are discussed below in brief.

\subsubsection{Habitat Loss, Degradation and Fragmentation}

Habitat loss, degradation, and fragmentation are important causes of known species population extinctions. The main cause of degradation and depletion of forests and wildlife are the human activity (anthropogenic pressure). Deforestation has led to reduction of rainfall, silting of rivers and dams, increase soil erosion, dryness in the air and increase in temperature, adversely affecting not only forestry but also agriculture and associated activities.

\subsubsection{Biotic Interference}

The collection of Non-timber Forest Produce (NTFP) in the form of small timber, fuel wood, and fodder by the people living in the surrounding villages in the project area and areas between the village and Reserved Forests are thereby exerting intensive biotic pressures on these resources. There is likelihood of increase in biotic interference with the influx of labour population during the construction of the project. This floating human population will exert serious pressure on the semi-natural ecosystems around the activity sites. Plantation of exotic species and invasion of non-native species like Lantana camara, Parthenium $s p$ and Eupatorium odoratum are also forms of biotic interference in this region.

\subsubsection{Timber Requirement}

The demand for timber and other wood produce is very high in the state for various activities like the construction of houses, business centers and other development activities owing to rapid population growth.

\subsubsection{Non Timber Forest Products (NTFP)}

Non Wood Forest Products (NWFP) constitute important source of livelihood for the poor and especially landless. There is abundance of Tendu leaves (Diospyrus melanoxylon), Mahua flowers (Madhuca indica), Sal leaves and seeds (Shorea robusta), different medicinal plants like Harra (Terminalia achebula), Bahera (Terminalia bellerica), Awnla (Emblica officinalis), wild fruit yielding species like Jamun (Syzygium cumini), 
Aam (Mangifera indica), etc. in the forest patches which are most of the times are over extracted.

\subsubsection{Grazing Pressure}

Various livestock species reared in the study area include cattle, buffaloes and goats. The grazing pressure leads to interference of livestock in the wilderness areas, direct competition for forage availability and degraded quality and reduction in the food availability for herbivores, transmission of communicable diseases and reduction in area of wilderness needed for the wildlife to sustain.

\subsubsection{Poaching}

It is one of the major causes for destruction of wildlife which is still in a practice by local dwellers in the study area. During the survey, list of Rare Endangered Extinct and Threatened (REET) species were recorded (Table 7).

Table 7. List of REET species of plants in the study area

REET plants within studied areas

Locally Endangered species
Locally Critically endangered and vulnerable
Herb: Drocera burmanii $\left(18^{\circ} 39^{\prime} 26.2^{\prime \prime} \mathrm{N} 8^{\circ} 17^{\prime} 46.7^{\prime \prime} \mathrm{E}\right.$ Alt-581m), Equisetum sp $\left(18^{\circ} 43^{\prime} 42.1^{\prime \prime} \mathrm{N} 81^{\circ} 15^{\prime} 35.2^{\prime \prime} \mathrm{E}\right.$ Alt-517m), Plumbago zeylanica $\left(18^{\circ} 39^{\prime} 45.5^{\prime \prime} \mathrm{N} 81^{\circ} 18^{\prime} 7.1^{\prime \prime} \mathrm{E}\right.$ Alt-580m.), Cyathea arborea syn Polypodium arboreum (Indian Tree fern) $\left(18^{\circ} 35^{\prime} 40.5^{\prime \prime} \mathrm{N}\right.$ $81^{\circ} 13^{\prime} 23.3^{\prime \prime} \mathrm{E}$ Alt-742m), Musa sp (Wild banana) $\left(18^{\circ} 35^{\prime} 30.8^{\prime \prime} \mathrm{N}\right.$ $81^{\circ} 13^{\prime} 11.1^{\prime \prime} \mathrm{E}$ Alt-718m), Uticularia sp $\left(18^{\circ} 39^{\prime} 9.1^{\prime \prime} \mathrm{N} 81^{\circ} 17^{\prime} 41.8^{\prime \prime} \mathrm{E}\right.$ Alt—583m)

Tree: Mallotus philippensis $\left(18^{\circ} 36^{\prime} 38.4^{\prime \prime} \mathrm{N} 81^{\circ} 18^{\prime} 52.6^{\prime \prime} \mathrm{E}\right.$ Alt—675m), Acacia concinna (Sikakai) $\left(18^{\circ} 35^{\prime} 29.3^{\prime \prime} \mathrm{N} 81^{\circ} 13^{\prime} 12.7^{\prime \prime} \mathrm{E}\right.$ Alt-744m), Strychnos potatorum $\left(18^{\circ} 37^{\prime} 23.3^{\prime \prime} \mathrm{N} 81^{\circ} 16^{\prime} 44.7^{\prime \prime} \mathrm{E}\right.$ Alt-626m)

$\begin{array}{lrlr}\text { Butea } & \text { monosperma, } & \text { Celastrus } & \text { paniculata, } \\ \text { Clerodendron } \begin{aligned} \text { serratum, } \\ \text { Curculigo }\end{aligned} \text { orchioides, } & \text { Madhuca } & \text { latifolia, } \\ \text { indica, } \\ \text { Curcuma aromatic } & \text { Terminalia } & \text { arjuna } \\ \text { Gymnema sylvestre, } & \text { (Low risk) } & \end{array}$

Pterocarpus marsupium

\section{Conclusion}

This case study demonstrates the major impact of mining on flora and fauna of Kirandul Iron Ore Mine. The study entails the total destruction of forest areas within the core zone. A detailed floral account only provides supportive evidence to ensure the survival of the herbivores and the carnivores, once the adjacent habitat can offer ecological niche for maintaining a prey predator base. The undulating mountain forest is expected to have the distribution of the recorded species over a wider area.

It is evident from the study that there are few plant species of rare occurrence in the buffer zone of Kirandul complex and few animal species within Schedule-I of Indian Wildlife (Protection) Act, 1972. These species are likely to be affected by mining project and related construction and other related activities like road construction, blasting, excavation for mining, and dumping of excavated material. However, human population pressure on land and biological resources are likely to exert pressure on the biological resources of the region. The existing natural ecosystems in areas constituting a rich bio-diverse region that need protection and further strengthening of conservation efforts.

Implementing scientific forest management may be helpful in some participatory forest management contexts, but it requires users to participate in an unfamiliar knowledge culture and appropriate support mechanisms need to be in place, particularly if scaling up its use across a country.

\section{Acknowledgement}

The authors are thankful to staffs of Indian Institute of Biosocial Research and Development, Kolkata for helping during extensive field work. Forest Department of South Bastar, Dantewada, Chhhattisgarh is acknowledged for their assistance during field survey.

\section{References}

Alvarez-Berríos, N. L., \& Aide, T. M. (2015). Global demand for gold is another threat for tropical forests. Environmental Research Letters, 10(1), 1-11. https://doi.org/10.1088/1748-9326/10/1/014006

Anonymous. (2008, November). Mexico: Mining causes ecocide in Coahuayana, Michoacan. WRM's bulletin $\mathrm{N}$. 
Anonymous. (2011, March 5). Mining, deforestation cause severe drought. The Asian Age, New Delhi.

Asner, G. P., Llactayo, W., Tupayachi, R., \& Luna, E. R. (2013). Elevated rates of gold mining in the Amazon revealed through high-resolution monitoring. Proceedings of the National Academy of Sciences, 110(46), 54-59. https://doi.org/10.1073/pnas.1318271110

Bennet, S. S. R. (1987). Name changes of flowering plants of India and adjacent region. Dehradun: Triseas Publishers.

Braun-Blanquet, J. (1964). Plant Associations, Principles of vegetation. Springer Verlag, Wien, 865.

Cain, S. A. (1938). The species-area curve. The American Midland Naturalist, 19(3), 573-581. https://doi.org/10.2307/2420468

Carvalho, G., Moutinho, P., Nepstad, D., Mattos, L., \& Santilli, M. (2004). An Amazon perspective on the forest-climate connection: opportunity for climate mitigation, conservation and development? Environment, Development and Sustainability, 6, 163-174. https://doi.org/10.1023/B:ENVI.0000003635.86980.c0

Carvalho, G., Nepstad, D., McGrath, D., Carmen, D., Vera Diaz, M., Suntilli, M., \& Barros, A. C. (2002). Frontier expansion in the Amazon: balancing development and sustainability. Environment, 44, 34-42. https://doi.org/10.1080/00139150209605606

Champion, H. G., \& Seth, S. K. (1968). A revised Survey of the forest types of India. New Delhi: Government of India Publications.

Charles, H., \& Dukes, S. (2007). Impacts of Invasive Species on Ecosystem Services. In W. Nentwig (Ed.), Ecological Studies (Vol. 193). Biological Invasions. https://doi.org/10.1007/978-3-540-36920-2_13

Devine, K., \& Fei, S. (2011). A review of impacts by invasive exotic plants on forest ecosystem services. Proceedings of the 17th Central Hardwood Forest Conference GTR-NRS-P-78.

Docena, H. (2010, December). Philippines: Deforestation through mining subsidized by CDM project. WRM's bulletin N 161.

Fearnside, P., \& Barbosa, R. (1996). The Cotingo dam as a test of Brazil's system for evaluating proposed developments in Amazonia. Environmental Management, 20, 631-648. https://doi.org/10.1007/BF01204136

Ganguli, S., Gupta Joshi, H., \& Bhattacharya, K. (2016). Vegetation structure ans species diversity in Garh jungle sacred forest, West Bengal, India. International Journal of Environmental and Agriculture Research, 2(9), $72-79$.

Gordon, D. R. (1998). Effects of invasive, non-indigenous plant species on ecosystem processes: lessons from $\begin{array}{llll}\text { Florida. } & \text { Ecological } & \text { Applications, } & \text { 975-989. }\end{array}$ https://doi.org/10.1890/1051-0761(1998)008[0975:EOINIP]2.0.CO;2

Griffiths, T., \& Hirvelä, V. V. (2008, January). India: Illegal aluminum refinery in Tribal lands in Orissa. WRM's bulletin N 126.

Harper, J. L. (1977). Population Biology of Plants. New York: Academic Press.

Hooker, J. D. (1872-1897). Flora of British India, London (Reprinted Edition 1973.

Jamir, S. A., Upadhaya, K., \& Pandey, H. N. (2006). Life form composition and stratification of montane humid forests in Meghalaya, northeast India. Tropical Ecology, 47(2), 183-190.

Kooroshy, J., Preston, F., \& Bradley, S. (2014). Cartels and Competition in Minerals Markets: Challenges for Global Governance. Chatham House research paper, 1-59.

Kumar, A., Khanna, K. K., \& Jha, A. K. (2005). Floristic Diversity of Chhattisgarh (Angiosperms). In Bishen Singh and Mahendra Pal Singh, Dehradun (p. 545). New Delhi: Oxford \& IBH Publishing Co. Pvt.Ltd.

Legris, \& Pascal (1982). Explanatory booklet on the map of South India. French Institute Pondicherry.

Mahar, D. (1988). Government policies and Deforestation in Brazil's Amazon region. Washington DC: World Bank.

Mather, A. S. (1991). Global Forest Resources. International Book Distributors. Dehra Dun, 311.

McDougal, C. (1997). Tiger Survey Report. A Report Submitted to Department of National Parks and Wildlife Conservation. Kathmandu, Nepal.

Mooney, H. F. (1942a). Sketch of the Flora of Bailadila Range in Bastar State, 3(7). 
Mooney, H. F. (1942b). Forest Advisor, and Eastern States Agency was published in as Indian Forest Record.

Mullick, B., \& Griffiths, T. (2007, March). India: Indigenous movement in Jharkhand challenge plans for industrial development that threatens to destroy Adivasi forests, farmlands and way of life. WRM's bulletin N116.

Philip, E. A. (1959). Methods of Vegetation study. Henry Holt \& Co. Inc.

Priyanka, N., \& Joshi, P. K. (2013). A review of Lantana camara studies in India. International Journal of Scientific and Research Publications, 3(10), 1-11.

Reddy, C., Babar, S., Giriraj, A., Reddy, K. N., \& Rao, T. (2008). Structure and Floristic Composition of Tree Diversity in Tropical Dry Deciduous Forest of Eastern Ghats, Southern Andhra Pradesh, India. Asian Journal of Scientific Research, 1, 57-64. https://doi.org/10.3923/ajsr.2008.57.64

Rodgers, W. A., Panwar, H. S., \& Mathur, V. B. (2000). Wildlife Protected Area Network in India: A review. WildlifeInstitute of India.

Sahu, S. C., Dhal, N. K., Sudhakar Reddy, C., Pattanaik, C., \& Brahman, M. (2007). Phytosociological Study of Tropical Dry Deciduous Forest of Boudh District, Orissa, India. Research Journal of Forestry, 1(2), 66-72. https://doi.org/10.3923/rjf.2007.66.72

Sanders, N. J., Gotelli, N. J., Heller, N. E., \& Gordon, D. M. (2003). Community disassembly by an invasive species. Proceedings of the National Academy of Sciences, 100(5), $2474-7$. https://doi.org/10.1073/pnas.0437913100

Sands, R. (2005). Forestry in a Global Context. CABI Publishing. https://doi.org/10.1079/9780851990897.0001

Shannon, C. E., \& Wiener, W. (1963). The Mathematical Theory of Communication. Urbana, IL: University llinois Press.

Shrestha, B., \& Basnet, K. (2005). Indirect methods of identifying mammals: A case study from Shivapuri National Park, Nepal. Ecoprint, 12, 43-58.

Simpson, E. H. (1949). Measurement of Diversity. Nature, 163, 688. https://doi.org/10.1038/163688a0

Singh, M. P. Dehradun. Journal of Polymer Materials. New Delhi: Oxford \& IBH Publishing Co. Pvt.Ltd.

Sonter, L. J., Herrera, D., Barrett, D. J., Galford, G. L., Moran, C. J., \& Soares-Filho, B. S. (2017). Mining drives extensive deforestation in the Brazilian Amazon. Nature Communications, 8, 1013. https://doi.org/10.1038/s41467-017-00557-w

Srnquist, M. E. (1981). The Social Organization of Tiger in Royal Chitwan National Park Nepal. Smithsonian Contribution to Zoology, 336, 14-98.

Staff, S. (2010, October 13). Mining deforestation nearly tripled between 2000-08 (Archives).

Swenson, J. J., Carter, C. E., Domec, J. C., \& Delgado, C. I. (2011). Gold Mining in the Peruvian Amazon: Global Prices, Deforestation, and Mercury Imports. PLoS ONE, 6(4), e18875. https://doi.org/10.1371/journal.pone.0018875

Tamang, K. M. (1982). The status of the tiger (Panthera tigris) and its impact on principle prey population in the Royal Chitwan National Park, Nepal (doctoral thesis). Michigan, USA: Michigan State University East Langsing.

Verma, D. M., Pant, P. C., \& Hanfi, M. I. (1985). Flora of raipur, Durg and Rajnandgaon. Botanical Survey of India, Howrah.

Whittaker, R. H., \& Levin, S. A. (1977). The role of mosaic phenomena in mosaic communities. Theoretical Population Biology, 12, 117-139. https://doi.org/10.1016/0040-5809(77)90039-9

\section{Copyrights}

Copyright for this article is retained by the author(s), with first publication rights granted to the journal.

This is an open-access article distributed under the terms and conditions of the Creative Commons Attribution license (http://creativecommons.org/licenses/by/4.0/). 